See discussions, stats, and author profiles for this publication at: https://www.researchgate.net/publication/322986341

\title{
Coordinate Subjects, Expletives, and the EPP in Early Irish
}

Article in Journal of Celtic Linguistics · January 2018

DOI: $10.16922 / \mathrm{jcl} .19 .5$

2 authors, including:

Elliott Lash

National University of Ireland, Maynooth

10 PUBLICATIONS 25 CITATIONS

SEE PROFILE

Some of the authors of this publication are also working on these related projects:

Project Chronologicon Hibernicum View project 


\section{Coordinate Subjects, Expletives, and the EPP in Early Irish ${ }^{1}$}

\section{Elliott Lash and Aaron Griffith}

Maynooth University and Universiteit Utrecht

This paper examines subject-verb agreement in Early-Irish sentences with coordinate subjects. We claim that Early Irish (Old and Middle Irish) is a 'variable agreement' language, which exhibits both singular and plural agreement with coordinate subjects. The type of agreement depends on adjacency between subject and verb and the valency of the verb. In particular, unaccusative and passive verbs exhibit both singular and plural agreement more frequently than transitive verbs. We argue that this is due to the availability of a default third person singular null locative expletive item, which controls singular agreement. Moreover, unaccusative and passive verbs also allow locative inversion with other PPs, leading to the same singular agreement. Furthermore, we suggest that, in contrast to Modern Irish, which lacks such an expletive, Early lrish could license its presence in intransitive/passive sentences because that stage of the language exhibited EPP-effects.

Keywords: Subject-Verb Agreement, Variable Agreement, null expletive, locative-inversion, EPP

\section{Introduction ${ }^{2}$}

In the Bardic Syntactical Tracts (BST), which describe the language of bardic poetry prior to 1500 (McKenna 1944 [1979]: ix), the following observation is made: 
(1)

'Tánuig Tadhg 7 Brian don bhaile' agus 'tángadar don bhaile Brian , Tad(h)g' as cert ann; ní cert a iollradh do dhénamh nó go ttí ní eatarra mur sin.

"Tadhg and Brian came (sg) to the village", and "Brian and Tadhg came (pl) to the village." That [i.e. the first one] is right. Using the plural number is not right, until something comes between them [i.e. the subject and the verb] like that [i.e. the second one].'

(McKenna 1944 [1979]: 41, 241.12-13)

The examples given in (1) show that singular agreement (tánuig) is appropriate with a conjoined subject such as Tadhg ${ }_{7}$ Brian when the subject immediately follows the verb. Plural agreement (tángadar) is only appropriate when the conjoined subject is further away from the verb. The tract continues to clarify the rule by presenting the following two examples:

'Tánuig Brían don bhrugh is Barrdhubh ...' cert; 'tánuig don bhrugh Brían 7 Barrdhubh' lochtach.

"'Brian came (sg) to the hill, and Barrdhubh...", right; "Brian and Barrdhubh came (sg) to the hill", wrong.'

(McKenna 1944 [1979]: 41, 241.15-17)

The first sentence in (2) shows that when the two noun phrases of the conjoined subject are separated from each other by an intervening phrase the singular verb is appropriate if at least one of the noun phrases immediately follows the verb. The second clarifies (1) by explicitly stating that the singular agreement with a conjoined subject that is not immediately after the verb is wrong. So, the rule is not merely that plural number is wrong when a conjoined subject with a singular first conjunct immediately follows but that the singular is also wrong if the conjoined subject does not immediately follow and the first conjunct is singular.

A further clarification of the rule is found in another manuscript of the syntactical tracts, where we find: 
(3)

'nir g(h)on D(omhnall) na T(adhg) mhe', 'nir ghonadar me Domhnall na T(adhg)', cert iad ar lorg an aguis agus cert sunnradh orra.

" Neither Domhnall nor Tadhg hit (sg) me", "neither Domnhall nor Tadhg hit (pl) me", they are right following (the pattern of) agus, and their subject is correct.' $^{3}$

(McKenna 1944 [1979]: 97, 71 $.34-5)^{4}$

The examples and their explanation in (3) mean that two noun phrases linked by the negative conjunction na/ná behave the same way as two noun phrases linked by the conjunction agus.

These statements in the BST serve as a useful means of framing the problem we wish to examine in this paper: what are the rules governing verbal agreement patterns with conjoined subjects for Early Irish. According to the BST, the rules for agus (earlier ocus) 'and' and na/ná 'not and/nor' can be summarized as follows:

a. If the verb and the first conjunct are adjacent, a first-conjunct analysis suffices.

b. If the verb and subjects are separated, the verb is plural. ${ }^{5}$

Our aim here is to examine whether these statements, made around 1500 and meant to apply primarily to Classical Modern Irish (Ó Cuív 1994), are valid for Early Irish (i.e., both Old and Middle Irish from approximately 600-1200). Further, we aim to explore what mechanisms are responsible for the attested subject-agreement patterns. For the purposes of this paper, conjoined subjects will include (at least two) noun phrases functioning as a subject linked by agus (ocus, 7 ), and na/ná. We also make the assumption that disjunctive noun-phrase subjects linked by nó 'or' work in the same way and therefore include such examples for consideration.

In what follows, we first outline and contextualize our corpus in section 2. In section 3, we discuss the data, specifying what types of examples we have excluded as well as those we have included. We also present the generalizations covering the subject-agreement patterns with coordinate subjects and discuss apparent exceptions. In section 4, we develop an analysis of the data by 
comparing and contrasting the Early-Irish data with Modern Irish as well as other languages with superficially similar subject-agreement patterns, such as Dutch and Arabic. We suggest that in Early Irish the subject-agreement pattern can be explained either as an expletive-associate construction that included an expletive with default third-person singular features or as locative inversion. Moreover, we suggest that the expletive is found in the canonical subject position, which is licensed by the EPP. Section 6 concludes the paper.

\section{The Data}

\subsection{Contextualization/Description of Corpus}

This paper focuses on the syntax of coordinated subjects in Old-Irish (600 CE-900 CE) and Middle-Irish (900 CE-1200 CE) texts. As is common in the field, the term 'Early Irish' will be used here as a cover term denoting the language of these two periods. From 1200 onwards, texts attest to a fairly standardized language generally referred to as Classical Modern Irish, but Early Irish is importantly different from Classical Modern Irish in both syntax and morphology, and its syntax is also fairly poorly studied.

This paper is based primarily on the Parsed Old and Middle Irish Corpus (POMIC, Lash 2014a), supplemented by a variety of additional texts from the period. The current version of POMIC consists of seventeen morphologically and part-of-speech tagged texts, which have been syntactically parsed. The corpus covers the late seventh century to the twelfth century. In addition to $P O M I C$, fifteen further texts were added, representing both the Old and Middle-Irish periods. Most of the texts in this additional corpus were written in the Old-Irish period (15 texts), while two, the Homily on the Betha Brigte and the passions and homilies in the Leabhar Breac are written predominately in Middle Irish. For a full list of the texts in the corpus, see the list of primary sources at the end of the paper.

\subsection{Overview of data}

In the following table we present the entire corpus of conjoined subjects from which examples are drawn to support the arguments in this paper. In subsequent sections, some of the examples will be excluded on the basis of various criteria. In the table, $\mathrm{VS}(\mathrm{X})$ refers to those examples with conjoined subject immediately 
following the verb and with optional following material. The pattern VXS(Y) refers to those examples with material intervening between the verb and conjoined subject. Verb Inflection notes the number of the verbal ending. The categories $\mathrm{Sg}+\mathrm{Sg}, \mathrm{Sg}+\mathrm{Pl}, \mathrm{Pl}+\mathrm{Pl}, \mathrm{Pl}+\mathrm{Sg}$ refer to the grammatical number of the conjoined subject elements. The conjoined subjects may either be continuous $(\mathrm{Sg} / \mathrm{Pl}+\mathrm{Sg} / \mathrm{Pl})$ or discontinuous $(\mathrm{Sg} / \mathrm{Pl} \ldots+\mathrm{Sg} / \mathrm{Pl})$. Both the first and second conjunct NPs are nominative. ${ }^{6}$ Some conjoined subjects have more than two conjoined elements; here we are only concerned with the first two, so a conjoined subject of the form $\mathrm{Sg}+\mathrm{Pl}+\mathrm{Sg}+\mathrm{Sg}$ would be categorized under $\mathrm{Sg}+\mathrm{Pl}$. Finally, we count duals as plurals for the purposes of this paper (because verbs have no dual endings, taking the plural instead). So a conjoined subject of the form $\mathrm{Sg}+\mathrm{Du}$ would be categorized under $\mathrm{Sg}+\mathrm{Pl}$. The superscript letters refer to the following sentences in (5), which exemplify each of the cells of the table.

Table I. Total Examples of Conjoined Subjects in Corpus

\begin{tabular}{|l|c|c|c|c|c|c|}
\hline $\begin{array}{l}\text { Subject } \\
\text { Position }\end{array}$ & $\begin{array}{c}\text { Verb } \\
\text { Inflection }\end{array}$ & Sg+Sg & Sg+Pl & PI+PI & PI+Sg & Totals \\
\hline \multirow{3}{*}{ VS(X) } & Singular & $128^{\mathrm{a}}$ & $10^{\mathrm{b}}$ & $7^{\mathrm{c}}$ & 0 & 145 \\
\cline { 2 - 7 } & Plural & $4^{\mathrm{d}}$ & 0 & $41^{\mathrm{e}}$ & $4^{\mathrm{f}}$ & 49 \\
\cline { 2 - 7 } & Ambiguous & 2 & 0 & 0 & 0 & 2 \\
\hline \multirow{3}{*}{ VXS(Y) } & Singular & $30^{\mathrm{g}}$ & 0 & $1^{\mathrm{h}}$ & 0 & 31 \\
\cline { 2 - 8 } & Plural & $10^{\mathrm{i}}$ & $2^{\mathrm{j}}$ & $4^{\mathrm{k}}$ & $2^{\mathrm{l}}$ & 18 \\
\cline { 2 - 8 } & Ambiguous & 1 & 0 & 0 & 0 & 1 \\
\hline \multirow{2}{*}{ Total } & & & & & 246 \\
\hline
\end{tabular}

The following examples (5a-k) illustrate the categories found above in Table I (other than the ambiguous categories, for which see below). Citations for each example found in table I are given in the appendix, part II. 
(5)

a. $\mathrm{V}-\mathrm{sg}, \mathrm{Sg}+\mathrm{Sg}, \mathrm{VS}(\mathrm{X})$

Atá $a=$ lecht,$\quad a=l i ́ a \quad$ forsint $=$ sligi ocon=glais.

be. $3 \mathrm{~S}$ his $=$ grave. $\mathrm{N}$ and his $=$ stone. $\mathrm{N}$ on.the $=$ road.D at.the $=$ stream. $\mathrm{D}$ 'His grave and headstone are on the road beside the stream.' $\left(T B C^{I} 1.1006\right)$

b. $\mathrm{V}$-sg, $\mathrm{Sg}+\mathrm{Pl}, \mathrm{VS}(\mathrm{X})$

Do.lluid $\quad a=b e n=s o m, n a=t r \bar{l}$ cóecait ban

$\mathrm{PV} \cdot$ come.PST.3S his=wife.N=3SM and the=three fifties.N women.G immailli fria.

together with.3SF

'His wife and the one hundred and fifty women together with her came.' (FB 1.327)

c. $\quad \mathrm{V}$-sg, $\mathrm{P} 1 .+\mathrm{Pl}$., $\mathrm{VS}(\mathrm{X})$

Do.baithed mēisi, a fuis $a=$ cuirnn ann. PV·drown.PSS.PST.3S his=servants.N table.G and his=horns.N in.3SN 'And his table servants and his drinking horns were lost therein.' (POMIC, TDH s.2)

d. V-pl, Sg.+Sg., VS(X)

Is amal ro $=$ bātar in $=$ corp , in $=$ cend

COP.3S like PRF=be.PST.3P the=body.N/A and the=head.N/A $o c=$ tepersain fhola.

at=drip.VN.D blood.G

'It is as if the body and the head were dripping blood.' (PH 1.1881)

e. $\mathrm{V}-\mathrm{pl}, \mathrm{Pl}+\mathrm{Pl}, \mathrm{VS}(\mathrm{X})$

Is ho=fethib gnitir comaccobra, imraiti.

be.3S from=kidneys.D work.PSS.3P desires.N and thoughts.N 'It is from the kidneys that desires and thoughts are worked.' (M1. 38 5) 
f. V-pl, Pl.+Sg., VS(X)

Ragmai-ne , Fergus for=Bernas $n$-Ulad.

go.FUT.1P-1P and Fergus.N on=Bernas.A Ulstermen.G

'I and Fergus shall go to Bernas of the Ulstermen.' $\left(T B C^{I} 1.1035\right)$

g. V-sg, Sg.+Sg., VXS(Y)

... co=r-rubud and Cáur mac Da Láth so.that=kill.PST.PSS.3S in.3SN PN.N and

Láth mac Da Bró , Foirc mac Trín-Aignech, $\quad$ Srubgaile mac Eóbith. PN.N and PN.N and PN.N

'... so that Caur mac Da Láth and Láth mac Da Bró and Foirc mac Trí n-Aignech and Srubgaile mac Eóbith were killed there.' ( $\left.T B C^{I} 1.1734\right)$

h. V-sg, Pl.+Pl., VXS(Y)

Et ní=dlegar dōib acht=cethri laa et cethri and $\mathrm{NEG}=$ owe.PSS.3S to.3P but=four.A days.A and four aidchi $\quad i=$ ndūnath, ...

nights.A in=encampment.D

'And nothing is owed by them but four days and four nights in encampment, ...' (POMIC, WMS s. 39)

i. $\quad \mathrm{V}-\mathrm{pl}, \mathrm{Sg}+\mathrm{Sg}, \mathrm{VXS}(\mathrm{Y})$

Doffuircet oco Eirr, Inell, Fóich, Fóchlam,

PV-come.3P to.3SM PN.N and PN.N PN.N and PN.N

$a=n d \dot{a}=$ ara .

their $=$ two $=$ charioteers. $\mathrm{N}$

'Eirr and Inell, Fóich and Fóchlam (their two charioteers) come to him.' $\left(T B C^{I} 1.333\right)$

j. $\quad \mathrm{V}-\mathrm{pl}, \mathrm{Sg}+\mathrm{Pl}, \mathrm{VXS}(\mathrm{Y})$

Bātar didiu int=imper $\quad, n a=r \bar{g}$ in- $a=$ tost

be.PST.3P also the=emperor.N and the $=$ kings. $N$ in-their=silence.D

'Moreover, the emperor and the kings were silent.' ( $P H 1.640)$ 
k. $\quad \mathrm{V}-\mathrm{pl}, \mathrm{Pl}+\mathrm{Pl}, \mathrm{VXS}(\mathrm{Y})$

At $\cdot[t]$ luchetar duit-siu, $\quad a=m o=$ choimdiu, th'uili=gnimrada

$\mathrm{PV}$-give.thanks.3P to. $2 \mathrm{~S}=2 \mathrm{~S} \quad \mathrm{VOC}=\mathrm{my}=$ lord $\mathrm{V}$ your=all=works. $\mathrm{N}$

$7 \quad$ t'uili nóib.

and $\quad$ your=all=saints. $\mathrm{N}$

'All your works and all your saints give thanks to you, oh my lord.' (POMIC, OIH s. 2)

1. $\quad \mathrm{V}$-pl, $\mathrm{Pl}+\mathrm{Sg}, \mathrm{VXS}(\mathrm{Y})$

'Ro=gellsam' ol=Mongan '; in=fili ucut

$\mathrm{PRF}=$ wager.PST.1P said=Mongán.N and the=poet.N yonder im=aided Fothaid Airgtig.' about=death.A Fothad.G Airgtech.G

“"We have wagered" said Mongán "the poet yonder and I, about the death of Fothad Airgtech."' (CM 2 §11)

\section{Exclusions}

The data cited above represent a broad-stroke gathering of data relevant to subject-agreement with conjoined subjects. There are, however, a number of reasons for excluding certain examples. The five main reasons for excluding examples are: (a) ambiguity of the verbal ending, (b) ambiguity in tokens where the conjoined phrase may not actually be the subject, but in apposition to the subject, (c) ambiguity between subject coordination and ellipsis, (d) subjecthood ambiguity with modal and aspectual auxiliary verbs, (e) different syntax for conjoined pronominal subjects. Note that some examples discussed below are excluded for more than one reason and thus appear multiple times in the following lists of excluded examples given in each subsection.

\subsection{Ambiguous Verbal Ending}

The first type of exclusion is exemplified by (6a-c). These are all of the examples of this type. 
(6)

a. For.comaidder .u.,$\quad$.o. in=presenti

$\mathrm{PV} \cdot$ preserve.PSS.3S/3P U and $\mathrm{O}$ in=present

7 in = preteritō.

and in=preterite

' $<\mathrm{U}>$ and $<_{\mathrm{O}}>$ are preserved in the present and preterite.' (Sg. 11 ${ }^{\mathrm{a}} 2$ )

b. In=chruth didiu fu·ndāilter animā et grātiā

the=way.N also PV·divide.PST.3S/3P spirit and grace

dē̄ sermō Dē̄ scìt.

God word God knows.3S

'The word of God knows the way, then, in which anima et gratia dei

(the spirit and grace of God) are divided.' (Wb. 33 ${ }^{\mathrm{b}} 19$ )

c. Fo.dáilter iar=suidiu biad ${ }_{7}$ lind dóib...

PV-divide.PSS.3S/3P after=that.D food.N and ale.N to.3P

'Food and ale is distributed to them afterwards...' (FB 1.187)

Example (6a) is excluded because, while the double consonant of the ending -dder could be understood as an attempt to represent the pronunciation of the plural ending / $\mathrm{d}^{\mathrm{j} e r}$ / (Thurneysen 1946: 23; GOI 31c), the fact that the scribe has placed a punctum delens on the first $d$ implies that the writing of this letter was a mistake and that it should be ignored. If that is the case, the writing would indicate a third person singular ending - der pronounced / $\mathrm{ojer} /$ (Lambert 1996: 190-1). ${ }^{7}$ Since we cannot be sure of the intent, the example is excluded. Examples (6b) and (6c) are excluded because the spellings are ambiguous as to number, due to a partial neutralization of dentals after $l$ (Thurneysen 1946: 88; GOI 139). ${ }^{8}$

\subsection{Apposition}

The second type of exclusion concerns appositional examples. There are two subtypes of apposition, the first of which is exemplified by (7). There are in total four such examples ( $B B r 62$ b p. $58.25, B B r 63$ b p. $68.15, B B r 64 \mathrm{a}$ p. 70.8, Sg. 5 15 ). 
(7) a. Lotar iar=sin dochum a=tire .i. Dubthach 7 go.PST.3P after=DIST toward their=land.G i.e. Dubthach.N and $\dot{a}=$ ingen.

his $=$ daughter.N

'Then they (Dubthach and his daughter) went to their country.' (BBr 62b p. 58.25)

b. Bemit=ne messe, tussu ar=gnúis in=dúileman be.FUT.1P $=1 \mathrm{P}$ me and you in=presence. $\mathrm{D}$ the $=$ creator. $\mathrm{G}$ ann $=\sin$.

at. $3 \mathrm{SN}=$ that

'Then we, you and I, will be in the presence of the creator.' (BBr 64a p. 70.8)

c. ...ind=luic hi=mbitis airdixi, $\quad e \quad 7 \quad 0$.
the=places.N in=be.IMPF.3P long.ones.N E and O
'...the places wherein the long vowels, "e" and "o", used to be.' (Sg. $\left.5^{\mathrm{a}} 15\right)$

These examples are excluded either because there is an explicit marker of apposition, as found with .i. = 'i.e.' in (7a), or because there is clearly a full subject NP to which the coordinate phrase is juxtaposed, even without a marker of apposition (7b). Furthermore, in (7c) the manuscript has a punctuation mark before the first conjunct of the coordinate phrase, here transcribed as a comma, indicating, perhaps, that the coordinate phrase is to be construed as in apposition to the actual subject, airdixi. It is interesting to note that the verb is always plural in these examples. Although we have excluded them here, they do conform to the proposal we make below (see the tree in (46)) that in some instances, particularly when a coordinate phrase is at the absolute end of the sentence, the coordinate phrase is not actually the true subject. Rather, the subject in such cases is in fact a plural null pronoun.

Two further examples could be argued to belong here as well: 
(8) a. Air is=inunn oin di $=a=$ tét $\quad$ les $=$ som, $\quad$ ind $=a c r<a>n n$

For $\mathrm{COP} .3 \mathrm{~S}=$ same one to $=$ which $=$ go. $3 \mathrm{~S}$ with. $3 \mathrm{SM}=3 \mathrm{SM}$ the $=$ sandal. $\mathrm{N}$

7 ind $=$ chos.

and the $=$ foot. $\mathrm{N}$

'For, in his opinion, it is to one and the same thing that the sandal and foot apply.' (M1. 56 1 )

b. Is=inunn $\quad d i=a=t e \overline{i t} \quad l e s=[\mathrm{s}] \mathrm{om} \quad a=n$ - Toseph' 7

COP. $3 \mathrm{~S}=$ same to $=$ which $=$ go. $3 \mathrm{~S}$ with.3SM=3SM the=Joseph and $a=n$ - 'Effraim'.

the $=$ Ephraim

"In his opinion, it is to the same thing that the name "Joseph" and “Ephraim” apply.' (Ml. 100'b)

The first example (8a) shows the same mark of punctuation as found in (7c), which might suggest that what follows it is appositional. On the other hand, while (7c) has an overt subject and overt appositional material, there is only one overt element in (8a), making it difficult to determine whether the NPs are the subject or are appositional to it. Example (8b) is formally identical to (8a), though without the mark of punctuation. Given the chance that these examples may have a subject in apposition, we exclude them here, though we can again note that if these are normal, non-appositional subjects, our account of agreement (see the discussion in 4.2) handles them perfectly well. ${ }^{9}$

A second subtype of apposition is found in sentences containing conjoined subject-like phrases headed by the prepositions eter 'between', acht 'but, except, only', and de 'of'. Conjoined subject-like phrase headed by acht occur two times in the corpus ( $F B$ 1.79, WMS s.39). In these examples, the acht phrase is in apposition to the true subject, which is usually not overtly expressed, although there is nothing preventing its overt expression. Compare (9a), with no overt subject, to (9b), which has an overt quantifier as subject. ${ }^{10}$ 
(9) a. Et ní=dlegar dōib acht=cethri laa et cethri and $\mathrm{NEG}=$ owe.PSS.3S to.3P but=four.A days.A and four aidchi $\quad i=$ ndünath, ... nights.A in=encampment.D

'And nothing is owed by them but four days and four nights in encampment, ...' (POMIC, WMS s. 39)

b....ní=dlegar ni dóib acht=cáin chuiscc nō $\mathrm{NEG}=$ owe.PSS.3S anything to.3P but=due.N reparation.G or mian ngalair ...

desire.N sickness.G

'...nothing is owed by them but the due of reparation or the desire of [one in] sickness]...' [our translation] ( $B B \S 25)$

Phrases headed by eter are likewise strictly appositive to the main subject, which may be not overtly expressed, as shown in (10). This is the only example of this type in the corpus.

$\begin{array}{lll}\text { Nó danō } & \text { is for=gúalaind Medba bátár } \\ \text { or moreover } & \text { COP.3S on=shoulder.D Medb.G be.PST.3P } \\ \text { immalle } & \text { eter=togán } 7 \text { én. } & \\ \text { simultaneously both=marten.A and bird.A } & \\ \text { 'Or, moreover, it is on Medb's shoulder they were simultaneously: } \\ \text { both a marten and a bird.' [our translation] }\left(T B C^{I} 1.926\right)\end{array}$

Finally, phrases headed by de (sometimes spelled $d o$ or $d^{\prime}$ ) are also appositive to the main subject, which is sometimes overtly expressed. In the corpus itself, there are two examples that show apposition to a null subject (11a-b). These should be compared to (11c), where the conjoined de-phrases are clearly in apposition with an overt quantificational subject $n i$ 'something, anything'. 
(11) a....dochumm a=rroibe d'iresechaib, d'fhirēnaib towards $\quad$ REL=PRF.be.PST.3S of=faithful.D and of=righteous.D $7 d o=$ Crīstaigib $7 \quad d o=$ dhesciplib Crīst innte... and of $=$ Christians.D and of $=$ disciples.D Christ.G in.3SF '...to where there were faithful and righteous ones and Christians and disciples of Christ.' (PH 1.222)

b. ...nāt $=b o \bar{l} \quad d o=\bar{u} a s a l \quad n \bar{o} \quad d$ 'isel

$\mathrm{NEG}=$ be.PST.3S of $=$ noble.D $\quad$ or $\quad$ of $=$ commoner.D

$n \bar{a}-r o-s=t e i l g \quad$ tri=frassa der...

NEG-PRF-3P=shed.PST.3S three. $\mathrm{A}=$ =showers. $\mathrm{A}$ tears. $\mathrm{G}$

'...that there wasn't any noble or commoner who didn't shed three showers of tears.' (AMC s.539b)

c. $N \bar{\imath}=$ fil do=threblait $n \bar{a} \quad d o=$ chumca na d'ingreim $\mathrm{NEG}=$ be $.3 \mathrm{~S}$ of $=$ trouble.D nor of $=$ might. $\mathrm{D}$ nor of $=$ persecution $n \bar{a} \quad d o=$ gortai $n \bar{a}$ güasacht, $n \bar{a} \quad d o=$ cloidem ní nor of=hunger.D and danger.D nor of =sword anything no- $m=$ eterscar $a=s a \quad \bar{o}=$ sheirc $\quad$ Crīst. PTC-1S=separate. $3 \mathrm{~S}=1 \mathrm{~S} \quad$ from=love.D Christ.G

'Neither trouble, nor might, nor persecution, nor hunger and danger, nor sword play will separate me from Christ's love.' (literally: 'There is nothing of trouble, or might, or persecution, or hunger and danger, or sword play that will separate me from Christ's love.' (PH 1.1930-2)

\subsection{Ellipsis}

The third type of exclusion involves two groups of sentences that could be classified as showing some sort of ellipsis. The first group contains examples of both gapping (12a), in which two remnants are left, and stripping (12b), in which only one remnant, in this case the subject, is left. While these phenomena are quite well defined and studied (for definitions see Johnson 2009: 293 on gapping and Hankamer and Sag 1976: 409 on stripping), we use the following operational definition for determining those examples that we exclude: instances in which the two possible subjects are non-contiguous. 
(12) a. Téit Cú Ruí di-a=thig , Munremur do=Emain go.3S Cú Roí.N to-his=house.D and Muinremar.N to=Emain.D Macha

Macha.G

'Cú Rói goes to his house and Muinremar to Emain Macha.' $\left(T B C^{I} 1.1623\right)$

b. Do.berar Findabair dó airi , rígi

PV-give.PSS.3S Findabair.N to.3SM for.3SM and rule.N

$a=$ cheniúil.

his=people. $\mathrm{G}$

'Findabair is given to him for it and sway over his people [has been given].'

$\left(T B C^{1} 1.1746\right)$

While other analyses are possible, the examples in (12), showing discontinuous subjects, are taken here as containing ellipsis. The other subtype, in which the second subject could be interpreted as being part of a small clause, is exemplified in (13). Although small clauses clearly are a different phenomenon, they are in practice frequently difficult to distinguish from possible ellipsis examples, and we therefore make no attempt to do so systematically here.

(13) a. Do choid

Dubthach $\quad \bar{i} a r=\sin \quad d i-a=t i g$

PV·PRF.come.PST.3S Dubthach.N after=DIST to-their=house.D and $a=$ chumal leis.

his=slave. $\mathrm{N}$ with.3SM

'After that Dubthach came to their house, and his slave girl (was/ came) with him' (BBr 62a p. 54.11)

b. Luid in=tarb iarom, cōeca samasca imbi go.PST.3S the=bull.N then and fifty.N heifers.G around.3SM $c o=m b o i \quad h i=S l e ́ i b \quad$ Chulind. until=be.PST.3S in=Slíab.D Cuilinn.G

'Then the bull went with fifty heifers around him to Slíab Cuilinn.' $\left(T B C^{I} 1.963\right)$ 
The ambiguity in the examples in (13) arises from the fact that it is unclear whether a verb ('came / went') has been elided or whether the structure following 7 'and' is a small clause. Modern Irish is well known for its propensity to use small clauses (Chung and McCloskey 1987; McCloskey 1997), and that Modern Irish agus 'and' frequently introduces small clauses is clear (Chung and McCloskey 1987: 175-6). While the facts for Early Irish are not well studied, it does appear that many of the same tendencies are present (Griffith 2012), and as such, an interpretation of examples like those in (13) as containing small clauses seems reasonable. The interpretation appears especially apt in (13b), where the verb of the second clause is singular: 'until he was in Slíab Cuilinn'. This makes most sense if 'the bull' is the sole subject of the main clause and the 'fifty heifers' part of a small clause.

Given the nature of corpus work, ellipsis and small clause analyses are difficult to prove for Early Irish. Nonetheless, the analyses are attractive in the cases given above, and as a result, the examples must be excluded from our analysis of conjoined subjects. In total there are 21 possible ellipses (gapping/stripping) or small-clause examples that we exclude on this basis alone ( $B B r$ 62a p. 54.11, $B B r 63$ a p. 62.38, $B B r$ 63a p. 62.41, $B B r 64 b$ p. 74.19, $C G \S 13 \mathrm{~b}, C M 2$ §9, $C M 4$ §4, LH s.98, M1 73² $2, M T$ s.175, $T B C^{l} 1.371, T B C^{l}$ 1.462, TBC $C^{I} 1.548, T B C^{I} 1.963, T B C^{I} 1.1623, T B C^{I} 1.1746, T D H$ s.6, TE 1.17980, TE 1.220, TP s.157, Wb 14 11$)$.

\subsection{Auxiliary Verbs}

For certain types of auxiliary verbs with modal or aspectual meanings, the subject of the sentence is potentially ambiguous. Examples of this type are given in (14) (deontic modal dlegair 'ought') and (15) (completive aspect auxiliary ro scáig 'finish'). In the corpus, there are four of these examples ( $F B$ 1.67, LH s.258, OIH s.3, TBC $\left.{ }^{I} 1.151\right) .{ }^{11}$

Ar=dlegair donaib=huilib dúilib atlugud buide do=Día for $=$ owe.PSS.3S from.the $=$ all.D elements.D thank.VN.N thanks.G to $=$ God.D $7 \quad a=$ bendachad... and him=bless.VN.N

'For, giving thanks to God and blessing him is due from all the elements...' (POMIC, OIH s. 3) 
In=tan $r o=$ mboi $\quad$ cách oc=gním $\quad a=s o s t a$,

when PRF=be.PST.3S every.N at=make.VN.D their=shelters.G

ro=scáig dóib=seom tuga $a=$ sosta,

$\mathrm{PTC}=$ finish.PST.3S to.3P=3P thatch.VN.N their=shelters.G and

fune $\quad a=$ mbíd.

cook.VN.N their=food.G

'When the others were making their shelters, they had finished thatching their shelters and cooking their food.' $\left(T B C^{I} 1.151\right)$

There are at least three possibilities for what constitutes the subject in these examples. On the one hand the conjoined verbal-noun phrases (atlugud buide do Día , a bendachad, tuga a sosta 7 fune a mbíd) may be construed as the subject. Under this analysis, the complement of the preposition would control a null PRO subject in the verbal-noun phrase. In example (14), the verbal nouns are translated with this assumption in mind, as gerunds. On the other hand, the prepositional phrase itself may be construed as having raised into the subject position of the main clause, along the lines of the translation of (15), where dóib-seom, literally 'for them', is here rendered simply 'they'. Another analysis, suggested by a reviewer is that the prepositional phrase is embedded within the verbal-noun phrase, in a way comparable to English infinitive clauses of the type [for X to INF]. According to this analysis, the subject of the main clause would be either the verbal agreement morphology itself or a null pronominal. Although undoubtedly there are ways of distinguishing these constructions from each other, this is a task for future research. Here, we view these examples as ambiguous and exclude them from the count of coordinate subjects.

\subsection{Pronouns}

The final type of token that has been excluded consists of examples in which the first conjunct is an overt or covert pronominal. These examples clearly have a different syntax from that of coordinated nominals. As has frequently been noted in the literature, the verb may agree with the entire coordinate structure (Ködderitzsch 1997; Meid 1968; Thurneysen 1925; McCloskey 1986, 1991): ${ }^{12}$ 
(16) a. Con'ráncatar $\varnothing$, Dubthach maccu Lugir ucc=Domnuch $\mathrm{PV} \cdot$ meet.3P pro $_{3 P}$ and Dubthach.N moccu Lugar.G at=Domnach.D Már Críathra.

Már.D Críathar.?

'He (literally 'they') and Dubthach, grandson of Lugar met at Domnach Már Críathar.' (POMIC, ABA, s. 66)

b. Ragmai=ne, Fergus for=Bernas n-Ulad. go. $1 \mathrm{P}=1 \mathrm{P}$ and Fergus.N onto=Bernas.A Ulstermen.G 'Fergus and I will go onto Bernas of the Ulstermen.' $\left(T B C^{I} 1.1035\right)$

As noted in Griffith (2009a), however, the verb may also agree with the first conjunct only:

(17) a. Téit $\varnothing \quad 7 \quad a=$ máthair $\quad$ for $=$ folog. go.3S pro $_{3 S}$ and his=mother.N on=sick.maintenance.D 'He and his mother go on sick-maintenance.' ( $C G \S 9)$

b. Con'érgim $=$ se $7 \quad$ Conchobar $\quad$ lais $=$ seom.

$\mathrm{PV} \cdot \operatorname{arise} .1 \mathrm{~S}=1 \mathrm{~S}$ and Conchobar.N with.3SM=3SM

"I and Conchobar rose up with him." (TBC 1.476$)$

No conditioning factor for the alternation has yet been noted. Since the subject-agreement facts appear to be different for coordinated pronouns than for coordinated NPs, we exclude examples with pronominal coordinands at this point, as we are attempting to determine the facts for NP-coordination. There are 16 examples of this type of exclusion (ABA s.66, $B B r 65 \mathrm{~b} \mathrm{p} .82 .6^{13}$, $C G \S 9, C M 2 \S 11^{13}, F B 1.448^{13}$, LH s.66, TBC 1 1. 476, TBC $1.653^{13}, T B C^{I} 1$. 986, $T B C^{I} 1.1035, T B C^{I} 1.2532, T B C^{I} 1.3145, T B F \S 8^{13}, T B F \S 13, T B F \S 24^{13}$, TPC s.52).

\subsection{Summary}

Table II gives the total number of excluded examples and Table III shows the number of examples that are considered in the analysis section below. 
Table II. Total exclusions

\begin{tabular}{|l|c|c|c|c|c|c|}
\hline $\begin{array}{l}\text { Subject } \\
\text { Position }\end{array}$ & $\begin{array}{c}\text { Verb } \\
\text { Inflection }\end{array}$ & Sg+Sg & Sg+PI & PI+PI & PI+Sg & Totals \\
\hline \multirow{3}{*}{ VS(X) } & V-sg & 17 & 5 & 0 & 0 & 22 \\
\cline { 2 - 7 } & V-pl & 3 & 0 & 4 & 2 & 9 \\
\cline { 2 - 7 } & Ambiguous & 2 & 0 & 0 & 0 & 2 \\
\hline \multirow{3}{*}{ VXS(Y) } & V-sg & 16 & 0 & 1 & 0 & 17 \\
\cline { 2 - 7 } & Ambl & 3 & 0 & 0 & 2 & 5 \\
\hline \multirow{2}{*}{ Total } & & 1 & 0 & 0 & 0 & 1 \\
\hline
\end{tabular}

Table III. Total examples to be analysed

\begin{tabular}{|l|c|c|c|c|c|c|}
\hline $\begin{array}{c}\text { Subject } \\
\text { Position }\end{array}$ & $\begin{array}{c}\text { Verb } \\
\text { Inflection }\end{array}$ & Sg+Sg & Sg+PI & PI+PI & PI+Sg & Totals \\
\hline \multirow{2}{*}{ VS(X) } & V-sg & 111 & 5 & $7^{\text {a }}$ & 0 & 123 \\
\cline { 2 - 7 } & V-pl & $1^{\mathrm{b}}$ & 0 & 37 & 2 & 40 \\
\hline \multirow{2}{*}{ VXS(Y) } & V-sg & $14^{\mathrm{c}}$ & 0 & 0 & 0 & 14 \\
\cline { 2 - 7 } & V-pl & 7 & 2 & 4 & 0 & 13 \\
\hline Total & & & & & 190 \\
\hline
\end{tabular}

Table III shows that the majority of examples conform to the rules extracted from the BST, summarized in (4) and again here for convenience: first-conjunct agreement is the rule for a verb beside the first conjunct of conjoined subjects; otherwise, the verb is plural. Interestingly, there exists a historical explanation for this fact. It has been argued in Griffith (2009b), that the coordinating conjunction ocus 'and' was in origin a WITH-coordinator (see Stassen 2000 for the term) with a meaning 'beside that which is'. As such, $A$ ocus $B$ 'A and B' originally had only $A$ as its head, and verbs would have agreed only with 
the first member of conjoined phrases. The etymology of ocus is thus most likely responsible for the first-conjunct agreement in Old Irish, though it should be noted that the etymology says nothing about how intervening material between the verb and the conjoined subject may have influenced agreement patterns. In any case, first-conjunct agreement would probably have been regular at first, but by the time of BST, intervening material between verb and subjects forced whole conjunct agreement. The examples in Table III above, however, reveal that there are exceptions to this explanation. It is to these that we now turn.

\section{Analysis}

In Table III, there are three types of examples that require further discussion, because they do not agree with the working assumption adopted above that the rules of the Bardic Syntactic Tracts hold also for Early Irish. The three example types are noted with superscripted letters the appropriate fields in table III. An overview of these three types is given in (18), which are repeated from $(5 \mathrm{c}),(5 \mathrm{~d})$, and $(5 \mathrm{~g})$.

(18) a. V-sg, Pl.+Pl., VS(X)

Do.baithed mēisi, $\quad a=$ fuis $a=$ cuirnn ann.

PV'drown.PSS.3S his=servants. $\mathrm{N}$ table. $\mathrm{G}$ and his=horns.N in.3SN

'And his table servants and his drinking horns were lost therein.'

(POMIC, TDH s. 2)

b. V-pl, Sg.+Sg., VS(X)

Is amal ro=bätar in $=$ corp , in $=$ cend

COP.3S like PRF=be.PST.3P the=body. $\mathrm{N}$ and the=head oc=tepersain fhola.

at=drip.VN.D blood.G

'It is as if the body and the head were dripping blood.' $(P H$ 1. 1881) 


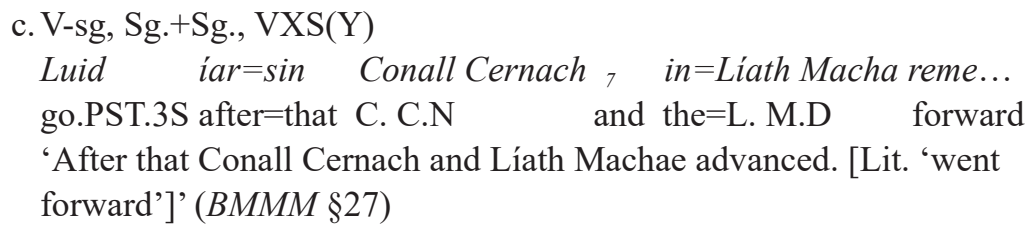

Example (18a) is representative of the seven sentences in the corpus whose verbs are singular and whose subjects are conjoined plural NPs. (18b) shows a plural verb with conjoined singular NPs as subject and no intervener. The largest group of 'exceptions' to the rules in (4) is represented by (18c), in which the conjoined subject of a singular verb is separated from the verb by an intervening element, here, the adverb phrase iar sin 'after that'.

Examples like (18a) may be grouped together with (18c), as we show below. Before dealing with this large group of 'exceptions' to (4), we will first offer an explanation for (18b), which is the only example of its kind. This example comes from the Passions and the Homilies from the Leabhar Breac, a heterogeneous collection of texts stemming mostly from the eleventh and twelfth centuries, i.e. the Middle Irish period (Dottin 1913; Ó Máille 1911; and more recently Herbert 2009: 33-4, citing Mac Donncha 1976). The simplest explanation is that the apparent conjoined subject is in fact in apposition to a null third-person plural pronoun (pro). In this analysis, the verb agrees with the pronoun. The approach taken here is similar to our analysis of examples like (7b), with the only difference being that in (7b), repeated here as (19), the pronominal subject is overt as a nota augens.

Bemit=ne $\begin{aligned} & \text { messe } \\ & \text { be.FUT.1 } 1 \mathrm{P}=1 \mathrm{P} \text { me ansu }\end{aligned}$ ar=gnúis you $\begin{aligned} & \text { in=dúileman } \\ & \text { in=presence. } \mathrm{D} \text { the=creator.G }\end{aligned}$
$\begin{aligned} & \text { ann=sin. } \\ & \text { at.3SN=DIST }\end{aligned}$

'Then we, you and I, will be in the presence of the creator.' (BBr 64a p. 70.8)

In (18b), there is no overt sign that the conjoined NPs are appositional, and so the analysis may appear to be ad hoc. However, it should be noted that 'the head' and 'the body' (the subjects of the verb) are mentioned in the sentence immediately preceding it in the text: 
Rucsat leō ìarum in=cend co=n-anōir 7 carry.PST.PRF.3P with.3P afterwards the=head.A with=honor.D and clascetul cusin $=$ corp

choir-singing.D to.the=body.A

'They [=the Roman people] then carried off the head with honor and great choir-singing to the body, [and it is as if they, the head and the body, were dripping blood, as if had been on that day that Paul had been beheaded]'. (PH 11. 1880-1)

It would appear that the conjoined subjects in (18b) are not really necessary for the sense but were added, perhaps for rhetorical purposes, to this homily. This explanation must remain somewhat speculative, given our fragmentary understanding of Early-Irish discourse structure, but it is at least a plausible explanation for why this otherwise innocuous example is indeed appositional.

We now turn to the analysis of examples like (18a) and (18c). We start by noting that all of the instances of type (18a) have a passive form: ro=gabad (AMC.157); at.n-agar (AMC.192); ro=gabad (AMC.216); ro=cenglad (AMC.281); at agur (AMC.577); do baithed (TDH s.2); do.baitheadh (TDH s.8). These verbs come from two texts written in Middle Irish, during which there was a tendency to replace the NP-promotion passive found in Old Irish with the arbitrary-subject passive (see Graver 2011, and Lash 2016 for details). Note that the verb in the NP-promotion passive may be singular or plural, depending on the number of the subject (the promoted object of the active verb), while the verb in the arbitrary-subject passive is always singular, since the subject is a null arbitrary pronominal meaning 'someone, something, uel sim.' and with default singular features. In addition, the patient/theme of the verb in this case remains in the internal argument position, where it is assigned structural Accusative Case. Presumably, as long as the traditional morphological case system remains in place in Irish, structural Accusative Case corresponds to morphological accusative case. ${ }^{14}$

All of the examples mentioned in the last paragraph from $A M C$ have subjects that are ambiguous between nominative and accusative, so they are ambiguous between an NP-promotion passive and an arbitrary subject passive: either they are straightforward arbitrary subject passives or they are NP-promotion passives with a seemingly unusual agreement pattern. This ambiguity makes these examples unusable, and so we will set them aside here. 
The two examples from TDH, however, are not ambiguous: they are clearly NP-promotion passives with subjects marked morphologically as nominative. Indeed, since TDH, written in the tenth century, is 200 years earlier than $A M C$, we would not expect the case system to be changed so early, so there is no possibility of construing the clearly marked nominative subjects as merely default 'common' case forms of later Irish. The TDH examples therefore remain unexplained under the normal rules for agreement. If we compare the verbs in these two examples to the verbs found in sentences of the type exemplified by (18c), a striking similarity is found: most of the sentences of the (18c) type have intransitive or passive verbs.

Before introducing these examples in more detail, it will be useful to clarify what our definition of 'intransitive' and 'passive' is. Here, we define these terms negatively: verbs qualifying as 'intransitive' and 'passive' lack features of 'transitive' verbs. We therefore define the term 'transitive' as follows (note that this is primarily a methodological definition, and not a theoretical one). Transitive clauses consist of a verb and two arguments: NP1, which is the subject (S), and NP2, which is the direct object (O) (i.e. it must be a theme, not any other theta-role). ${ }^{15}$ Lacking one of these arguments (unless through relativization or clefting) means that the verb is not transitive. The linear order of elements and the presence of pronominal arguments do not affect the transitivity, with one exception: third-person NP-promotion passives are 'true' passives (having only one argument), while 1st and 2nd person 'passives' are in fact transitives; i.e. NP1 is the pronominal agreement (i.e. the $3 \mathrm{rd}$ person 'passive' ending) and NP2 is the infixed pronoun representing O. In other words, they are arbitrary-subject passives. According to these guidelines, we can see in examples (21a-h) that all instances of type (18c), save three (see ex. 22), are non-transitive. 
(21) a. Ansait and $=\sin$ trá co=rrubud and Caur waited.3P in.3SN=DIST so so=PRF.kill.PST.PSS.3S in.3SN Caur.N mac Da Láth 7 Láth mac Dā Bró 7 Foirc mac son.N Dá Láth.G and L.N son.N Dá Bró.G and Foirc.N son.N Trín-Aignech, Srubgaile mac Eóbith. Trí Aignech.G and Srubgaile.N son.G Eóbith.G 'Now, they waited there then so that Caur mac Dá Láth and Láth mac Dá Bró and Foirc mac Trí n-Aignech and Srubgaile mac Eóbith were killed there.' $\left(T B C^{I} 1.1734\right)$

b. 7 cid indar leó=som bai aici=seom $a=$ sechna and even seem with. $3 \mathrm{P}=3 \mathrm{P}$ be.PST.3S at.3SM=3SM its=avoid.VN.N 7 a=imdegail fair and his=protect.VN.N on.3SN 'And it even seemed to them (?) that he was avoiding it and he (was) protecting himself from it...' $\left(T B C^{I} 1.2575\right)$

c. Luid iar=sin Conall Cernach , in=Liath Macha reme... go.PST.3S after=DIST PN.N and the=PN.D forward 'After that Conall Cernach and Líath Machae advanced.' [Lit. 'went forward'] (BMMM §27)

d. Fo'gní danō ailli mési, 7 altugud $\mathrm{PV} \cdot$ is.practiced.3S also grace.N table.G and thanks.N lais $=$ som aidchi Lúoin. with.3SM=3SM night.D Monday.G 'He also usually does a table grace and thanksgiving on Sunday night.' [Lit. 'A table grace and thanksgiving on Sunday night is his practice/is practiced by him.'] (POMIC, MT s. 67) 
e. An=tan $\operatorname{tra}$ do- $n<d>\cdot t i c \quad$ aitherriuch bläth, bēogud, when now PV-LOC'come.3S back color.N and life.N $a=$ mmarbad $\quad$ cach $=l a=$ sel iarum dō $\quad a=m b \bar{e}$ ogud their=mortify.VN.N at.one.time.A then to.3SM their=revive.VN.N ind $(t)=$ ale di-a $=$ marbad $\quad$ ind $=$ cruth $=\sin .{ }^{16}$ the $=$ other from-their=die.VN.D the=way=that.D 'Now, when colour and life comes back there, he alternatively mortifies and revives them from their dying state in this way.' (POMIC, MT s. 327)

f. In=tan $\operatorname{tr} \bar{a} \quad m b \bar{\imath} s$ isna=rīaglaib 'superponat' nó when so be.HAB.3S.REL in.the=rules.D superponat or 'superpositiō', do=leith fitt 7 do=leith troscud, superposition to $=$ half.D ration.D and to $=$ half.D fast.D is $=d \bar{i} r \quad$ in $=\sin$.

COP.3S=proper.N the $=$ DIST

"When, however, there is in the Rules "superponat" or "superposition", that is properly applicable to a half ration and half fast.' (POMIC, MT s. 491)

g. Dorrochair and cétamus Mess Dead mac Amargin PV·PRF.fall.PST.3S in.3SN first Mess.N Deäd.N son.N Amairgen.G 7 Briannán Brethach 7 Connlae 7 Béothach 7 and Bríannán.N Brethach.N and Connlae.N and Beóthach.N and Conáed mac Mornai, sochaide olchenae.

Conáed.N son.N Mornae.G and many.N besides 'There fell accordingly there first, Mess Deäd mac Amairgin and Bríannán Brethach and Connlae and Béothach and Conáed mac Mornai and many others besides.' (TE 1. 113)

h. Atá sund ocut a=máthair , $a=n$-athair, i. Rían , BE.3S here yonder their=mother.N and their=father.N i.e Rían.N and Gabar , Finnabair riside $a=n$-athar Ríangabra Gabar.N and Finnabair.N story.teller.N their=parents.G Rían-Gabar.G 'Over there is their mother and their father (Rían and Gabar) and Finnabair, the story teller of their parents, Rían and Gabar.' (LMDD §29) 
i. Do.chuaid

$$
\text { ass in }=\text { drai }, \quad \text { in }=\text { chumal lais. }
$$

PV·PRF.go.PST.3S out.3SM the $=$ druid and the $=$ slave.N with.3SM 'The druid and the female slave with him went out.' (BBr 62a, p. 54.35)

j. Luid iarom in=drai $\quad 7$ in $=$ chumal cona=hingin go.PST.3S afterwards the $=$ druid. $\mathrm{N}$ and the $=$ slave. $\mathrm{N}$ with.

$i=$ crich Connacht.

her=daughter.D into=territory.A Connachtmen.G

'The druid and the female slave with her daughter went afterwards into the territory of the Connachta.' ( $B B r 62 \mathrm{a}$, p. 56.25)

k. Do-fuit immorro isin=sruth in=clām diumsach PV-fall.PST.3S however in.the=stream.A the=leper.N haughty.N $7 \quad a=b o ́ \quad$ fo-a=thairr ... and his $=$ cow.N under-his=stomach.D 'But the haughty leper and his cow under his stomach fell into the stream...' (BBr 65a pg. 78.29)

The three examples with transitive verbs are given in (22).

(22) a a...fo.ngera cach=n-êrnail, oire $\quad$ nundem $=$ membur PV-inflame.SBJ.3S every=part.A since PTC.COP.1P=member.N uili $d u=D \bar{e} a, \quad$ nach $=$ cēssath ocus na=galar bess all of $=$ God.D any=suffering. $\mathrm{N}$ and any=illness.N be.SBJ.3S.REL faire $=$ chomnessam. on.its=neighbor.D '...that whatever suffering and whatever ailment that is on its neighbor should inflame every part, since we all are members of God.' (POMIC, CH s. 22) 
b. ... mádo'ní aithrigi iarum ind=gilde nó in=mnao $\bar{l}$

if $\mathrm{PV} \cdot \mathrm{do} .3 \mathrm{~S}$ penance.A then the=boy. $\mathrm{N}$ or the=woman.A don $=$ peccad $=$ sin.

for.the $=\sin . \mathrm{D}=$ that

'.. if the boy or the woman do penance thereafter for that sin.' (POMIC, MT s. 263)

c. Ro=iarfacht de in=drai $\quad$ i $a=b e n$ :

$\mathrm{PRF}=$ ask.PST.3S of.3SM the $=$ druid. $\mathrm{N}$ and his=wife.N

'In=maith lesaiges inn=óg in=áirge?'

Q.COP.3S=well tend.3S.REL the=virgin.N the=herd.A

'The druid and his wife asked of him, "does the virgin tend the herd well?"” $(B B r$ 63a p. 60.39)

The presence of an intervener and singular agreement in these examples is surprising if, as it seems, the pattern is generally limited to intransitives and passives. However, we propose that the examples in (22) are not in fact exceptional. With regard to (22a), there is reason to believe that this example reflects an older syntax, stemming from a time when first conjunct agreement was stricter than in Classical Old Irish. As was noted above, ocus was originally a WITH-coordinator, for which first-conjunct agreement would be expected. Example (22a) appears in the Cambrai Homily, which is well-known for containing a number of archaisms, so it is quite plausible that the text also contain a syntactic archaism in the preservation of first-conjunct agreement in a context in which it was given up in later texts of the Classical Old Irish period. ${ }^{17}$ If we are correct, the apparent exception offered by example (22a) need not concern us.

There are two possibilities for explaining (22b). First, one might note that the subject ind gilde nó in mnaoi actually contains no obvious coordination between two nominative subjects, since the second conjunct is in the accusative case. ${ }^{18}$ The sole nominative subject, ind gilde, is singular and thus, the verb is singular. However, if one wishes to view the accusative case here as a 'scribal error', another possibility exists, since this example conforms to our proposals for the clausal structure of Old Irish given in (34) below. That is, we could understand iarum in its discourse-oriented meaning and not its temporal one. Then, the object could be topicalized and the subject in SpecTP. 
The same possibility exists for (22c). See 4.2 below for further details on our assumptions about clause structure.

The rest of this article will be concerned with arguing for an analysis of the more numerous non-transitive group with singular verbs, which contrast with the observation in the BST that conjoined subjects placed far from the verb require plural verbs.

\subsection{Analysis: Variable Agreement}

The alternation between singular and plural verbal agreement with coordinate subjects is reminiscent of 'variable agreement' languages, such as Arabic (Johannessen 1998), Dutch (van Koppen 2007), and Polish (Citko 2003), where coordinate subjects can trigger either first-conjunct agreement, resulting in a singular verb, or agreement with the whole coordinate structure, resulting in a plural verb. For Arabic, Johannessen (1998: 31) shows that the alternation is tied to position. First-conjunct agreement is generally found with Verb-Subject order (23a), while plural agreement is found with Subject-Verb order (23b). Polish is similar to Arabic in this regard, as shown in (24). Russian, Hebrew, and Brazilian Portuguese are in some ways similar to Polish and Arabic (for references dealing with these languages see Van Koppen 2007: 141).

(23) a. Gatal

$$
\text { 'el-walad we-l-banaat 'el-bisse. }
$$

killed-3sg.m the-boy and-the-girls the-cat

b. 'el-walad we-l-banaat gataluu 'el-bisse.

the-boy and-the-girls killed-3pl.m the-cat

'The boy and the girls killed the cat.' [Palestinian Arabic]

(Van Koppen 2007: 122, ex.1)

(24) a.Do pokoju weszła młoda kobieta $i$ chłopiec.

to room entered-3sg.f [young woman and boy]

'Into the room walked a young woman and boy.' 
b. młoda kobieta $i$ maty chtopiec weszli /*weszła do pokoju young woman and small boy entered $_{\mathrm{PL}}$ to room 'A young woman and small boy entered the room.'

(Van Koppen 2007: 141, ex.39)

In various dialects of Dutch, the situation is somewhat more complicated because alternation in agreement is tied to position, locality, and the Subset Principle. For Tegelen Dutch and Tielt Dutch, Van Koppen (2007) shows that first-conjunct ('partial') agreement is found when a probe locally c-commands a coordinate subject whose first conjunct has features corresponding to the most specific features of a particular morphological agreement paradigm (25a). If the morphological agreement paradigm does not have features corresponding to the first conjunct, agreement is with the full coordinate structure (25b) ('resolved agreement'). ${ }^{19}$

(25) a.Ich dink de-s doow en ich ôs kenne treffe

I think that- $2_{\mathrm{SG}}\left[\mathrm{you}_{\mathrm{SG}} \text { and I }\right]_{1 \mathrm{PL}}$ each.other $_{1 \mathrm{PL}}$ can- $_{\mathrm{PL}}$ meet

'I think that you and I can meet each other.'

(Tegelen Dutch, Van Koppen 2007: ex.3a)

b. Oa-n Bart en Liesje nie ipletn ...

if- $_{3 \mathrm{PL}}[\text { Bart and Liesje }]_{3 \mathrm{PL}}$ not watch.out

'When Bart and Liesje don't watch out ...'

(Tielt Dutch, Van Koppen 2007: ex.3b)

Additionally, intervening material between the probe and the coordinate subject prohibits local c-command, blocking first-conjunct agreement (26a) ${ }^{20}$ Finally, when the coordinate subject precedes the probe (in this case T), full agreement is found (26b), as in Arabic, Polish, and other variable-agreement languages.

(26) a....det/?de-s auch doow en Anna komm-e that / that- ${ }_{2 \mathrm{SG}}$ also $\left[\mathrm{you}_{\mathrm{SG}} \text { and Anna }\right]_{2 \mathrm{PL}}$ come- $_{\mathrm{PL}}$ '... that you and Anna will also be coming.' 
b. Doow en Marie *ontmoet-s/ontmoet-e uch $\left[\mathrm{you}_{\mathrm{SG}} \text { and Marie }\right]_{2 \mathrm{PL}}$ meet- ${ }_{2 \mathrm{SG}} /$ meet- $_{\mathrm{PL}}$ each.other ${ }_{2 \mathrm{PL}}$ 'You and Marie will meet each other.' (Tegelen Dutch, Van Koppen 2007: ex.35)

Early Irish does not work like any of these languages. The coordinate subject is always after the verb with which it agrees. This means that both full and partial agreement occur under c-command. Additionally, locality does not play a straightforward role in distinguishing between full and partial agreement, as shown in example (27).
a. Ōr do.baitheadh $\quad a=$ cuirnn $\quad, a=c \bar{u}$ aich $a c=\bar{A}$ th since PV $\cdot$ drown.PSS.3S his=horns.N and his=quaighs at=Áth.D Enaigh $\bar{u}$ as $=$ Eas Rüaidh ...
Enach.G above=Ess.D Rúad.G
"Since his horns and his "quaighs" were lost (lit. drowned) at Áth Enaig above Ess Rúaid...' (POMIC, TDH s. 8)
b. An=tan trā don $\langle d>\cdot$ tic aitherriuch bläth 7 bēogud ... when now PV-LOC·come.3S back color.N and life.N 'Now, when color and life comes back there...' (POMIC, MT s. 327)

In both of these examples the verbs are marked as third-person singular. In (27a), both the first conjunct and the whole coordinate subject are plural. If Early Irish worked like Dutch, we should expect third-person plural marking on the verb. Similarly, in (27b), the coordinate subject (consisting of two singular nouns) is separated from the verb by the adverb aitherriuch, and we should expect third-person plural marking on the verb. One significant difference between the languages discussed above and Early Irish is the fact that the majority of verbs with 'partial' agreement (i.e. third-singular agreement with coordinate subjects), in which the subject is separated from the verb by an intervener, are either passive or intransitive. This seems to be an important condition on the appearance of 'partial' agreement in this language and one that should be incorporated into a proper analysis of the construction. We do so in the following section. 


\subsection{Analysis: Expletives and Locative Inversion}

Comparative syntactic research dating from Perlmutter (1979) onwards has shown that intransitive verbs may either be unaccusative or unergative. Unaccusative verbs have a single internal argument, while unergative verbs have a single external argument. Passives are like unaccusatives in that they too have a single internal argument. We adopt the standard analysis that internal arguments are internal because they are merged in object position within the VP (Burzio 1986). It is worthwhile noting that the majority of the verbs in (21) may in fact be viewed as either formally passive, or unaccusative from a purely semantic point of view (for semantic properties of unaccusative predicates see Mendikoetxea 2006, Levin and Rapapport Hovav 1995, and Van Valin 1990). For convenience, we list the verbs in (28).

(28) a. $\quad c o=r r u b u d$ 'so that $\mathrm{X}$ was killed'

b. bai 'was (LOC)'

c. luid 'went'

d. fo gni la 'is practiced by'

e. $\quad d o n[d] \cdot t i c c$ 'comes there'

f. $\quad m b i \bar{s}$ 'is usually (LOC)'

g. dorochair 'fell'

h. atá 'is (LOC)'

i. do.chuaid 'went (perf.)'

j. luid 'went'

k. do.fuit 'fall'

These verbs represent four different classes, atelic statives (28d), change of state/location verbs (28c, e, g, i, j, k), existentials (28b, f, h), and passives (28a). The first three types are generally thought to be unaccusative, and indeed in many languages verbs having these meanings show syntactic unaccusative properties. As we have mentioned before, passives pattern with unaccusatives in that their subject originates in the internal argument position.

A further observation we made is that aside from the passive examples like (18a) and (27a), the non-transitives all have a conjoined NP subject that is separated from its verb by an intervener, for instance, the adverb iarum in (29). 


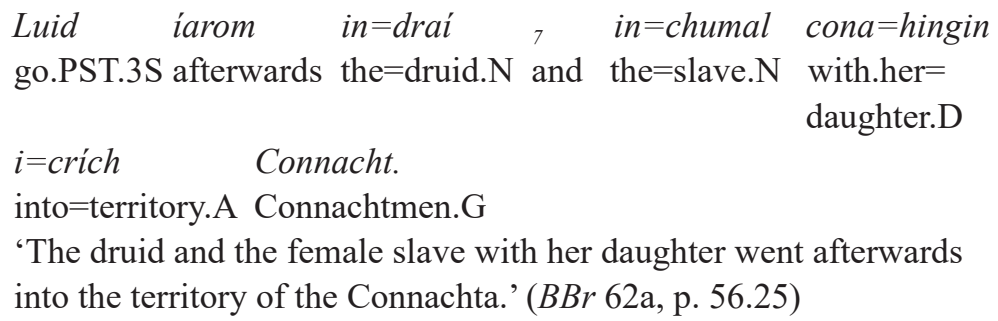

If there were some way to prevent internal arguments of passive or unaccusative verbs from moving further upward, this would mean that in many cases in Early Irish the subject would remain in its original internal argument position, to the right of intervening material.

A plausible analysis, given the evidence presented thus far is that Early Irish had a null expletive with default third-person singular features that triggered third-person singular subject-verb agreement. This may seem surprising given that Early Irish is clearly a null subject language, where agreement alone typically marks the subject. Overt expletives, such as those found in French and English are in a sense not unusual because in these languages every clause typically must have an overt subject. This is of course not the case in null subject languages. Indeed, null expletives have been previously seen as merely theory-internal items proposed because the EPP was claimed to be universal. Sheehan (2006: 236) sums up the Minimalist problem with null subjects nicely, writing the following:

(30) 'the behaviour of languages such as English and French ... have persuaded many of the existence of a universal EPP, whereby every sentence requires a grammatical subject. This in turn led to the positing of null expletives whose existence is justified merely as a means to satisfy the EPP, and for the existence of which there is no independent evidence.'

Additionally, Sheehan points out that circularity is not the only issue many have had with null expletives. They are also problematic because they have no LF or PF representation. That is to say, they are supposedly neither interpretable at LF, since they lack semantic features (hence the term 'expletive'), nor interpretable at PF, since they obviously lack phonetic form, 
being null. These are serious problems with positing a null expletive in a null subject language. Nonetheless, Sheehan $(2006,2016)$ does precisely that, arguing that data from various null subject Romance languages can only be understood if one posits an expletive and that this expletive actually does have certain semantic repercussions, which alleviates the issue of interpretability.

She shows that in Spanish, Italian, and European Portuguese free inversion (i.e. VS order) is licensed in 'out-of-the-blue' contexts (i.e. as answers to the question 'what happened'?) and that inversion is not possible with an unergative verb if there is an overt locative post-verbally. Consider the contrast between the European Portuguese sentences in (31) and (32). The supposition is that in (31b) there is a null locative expletive which corresponds to the 'deictic' interpretation at LF. The ungrammaticality of (32b) implies that free inversion is only licensed when the (null) locative is before the verb, occupying the usual subject position.

$\begin{array}{cllll}\text { (31) a. } O & q u e & e & q u e & \text { aconteceu? } \\ \text { the what is that happened }\end{array}$

'What happened?'

b. Ligou o João.

rang the João

'João rang (here)' (Sheehan 2006: 237, ex. 5)

(32) a. $O$ que é que aconteceu?

the what is that happened

'What happened?'

b. *Ligou o João/alguém para o jornal. rang the João/someone for the newspaper

'João rang the newspaper.' (Sheehan 2006: 238, ex.6)

Furthermore, Sheehan shows that a similar argument works for unaccusative verbs, which, unlike unergatives, exhibit inversion even when there is an overt locative PP, as long as the subject is indefinite. Because of this definiteness 
effect, she argues that the null expletive corresponds more or less directly with the overt English expletive 'there', which imparts the interpretation of an existential quantifier at LF. Consider (33).

a. $O$ que é que aconteceu?
the what is that happened
'What happened?'

b. Chegou alguém ao colégio. arrived someone to-the school 'Someone arrived at school.'
c. * Chegou o João ao colégio. arrived the João to-the school. (Sheehan 2006: 238, ex. 7)

Arguments such as these seem to show that positing an EPP and null expletives in a null subject language is viable, to extent that the data warrant it. We therefore follow Sheehan in assuming that expletives are not intrinsically impossible in a null subject language. Irish of course differs from these languages in having unmarked verb initial order, among other differences. ${ }^{21}$ This means that the arguments for a null subject are necessarily different from Romance languages, which are basically SVO. Additionally, since expletives need to be licensed in some position, our proposal may mean that Early Irish differed from Modern Irish in being subject to the traditional EPP (see McCloskey 2001 who argues that Modern Irish does not have a position for expletives). In sum, we suggest that Early Irish is an example of a language with extremely rich verbal agreement, possible $\mathrm{V}>\mathrm{T}$ movement (followed by V $>$ C movement, see Carnie, Harley and Pyatt 1994, Carnie 1995, and Lash 2014b; for arguments against such an analysis, see Newton 2006) and a possible reflex of the EPP which forces XP movement to SpecTP, or the insertion of an expletive.

We assume that subject-verb agreement occurs between an item in SpecTP and the verb in T. Both elements may later move upwards: the NP to some higher discourse-oriented position (for which see below) and the verb to C. This would mean that first conjunct agreement, like all subject-verb agreement, 
occurs between an NP in SpecTP and the verb in T. The question we attempt to answer here is what happens when NPs appear not to be in SpecTP.

To answer this question, it will be useful to clarify further our assumptions about clause structure. Essentially, we adopt the clause structure for Early Irish that is outlined in Lash (2014b). There, at least two subject positions are proposed: 'Subject-1' and 'Subject-2'. These are informal terms which derive from the fact that most often, it is subjects which occupy these positions. However, at least with regard to 'Subject-1', Lash (2014b) points out that any phrasal item could be placed in this position, as long as it fulfills the specific semantic conditions for this position, which we introduce below. On a purely formal level, the two positions are specifiers. The first is a specifier of a modal functional head that is merged just below CP. The second is, for the most part, the 'canonical' subject position in SpecTP.

In many cases, Lash (2014b) shows that the two positions can be distinguished on the basis of the position of the subject relative to the set of discourse-oriented modal particles/adverbs together with one modal prepositional phrase given in (34). Subject NPs have different semantic properties depending on which position they are found in. This is summarized in (35-36). As implied above, non-subject XPs, such as objects, may be placed in 'Subject-1', if they fulfill these semantic criteria.

(34)a. danó 'also, in addition to, besides, too, further, as well'

b. didiu 'therefore, hence, moreover, also'

c. ém (ám, óm) 'truly, indeed, in sooth, then'

d. etir 'at all'

e. iarum 'then'

f. immurgu 'however'

g. $\quad l a+N P$ 'in the opinion of NP'

h. trá 'then, therefore, so, indeed, however, but, on the other hand'

(modified from Lash 2014b: 281-2, ex. 11) 
(35) Definite NPs and proper names

a. 'Subject-1': salient topics (background information that is relevant for the text as a whole) or continuing topics (information of immediate relevance for the section of discourse in which the sentence is found).

b. 'Subject-2' new information or reintroduced information (i.e. switch topics).

(36) Indefinite NPs and Quantifiers

a. 'Subject-1': Wide scope, i.e. they have specific or generic interpretation.

b. 'Subject-2': Narrow scope interpretation, i.e. they are existentially quantified.

The discourse-oriented modal particles are distinct from another set of adverbs or adverbial phrases. These fall into at least two groups: purely temporal adverbs/adverbials (37a) and aspectual adverbs/adverbials (37b).

(37) a. iarum 'afterwards', íar sin 'after that', la suidiu/sodain 'thereupon', cétamus 'first'

b. asennath 'finally', aitherriuch 'finally', beös 'still', indossa 'just, now', fo di 'twice' (fo thri 'thrice', etc.), fo chétóir 'at once, immediately'

Following Lash (2014b), we adopt the view, originating in Cinque (1999), that the adverbials in $(34,37 \mathrm{a}-\mathrm{b})$ are arranged in the following (simplified) sequential and hierarchical order: modal $>$ temporal $>$ aspectual VP. This means that aspectual adverbs are specifiers of aspectual phrases that merge with the VP. Temporal adverbs are specifiers of temporal phrases merged with the aspectual phrase combined with the VP. Finally, modal adverbials, which we take to be heads for the most part, are merged last. Here, we make the assumption that TP is found between modal adverbs and the rest of the sequence. This seems reasonable, given the close semantic connection between Tense and temporal adverbs. The sequence discussed here is represented in (38). 


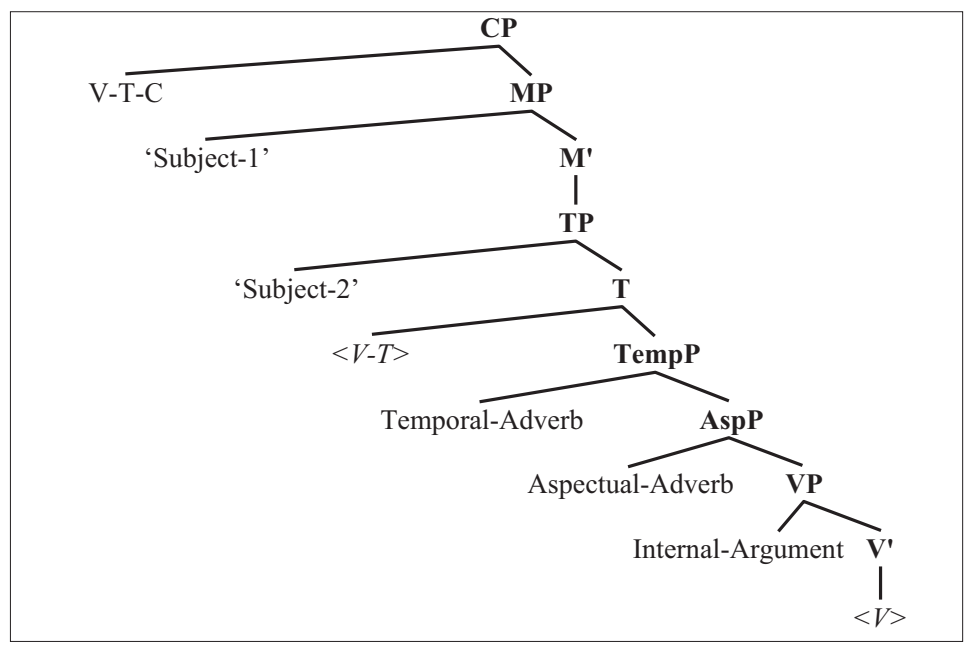

The analytic consequence of this assumed clausal structure is that subject NPs before discourse-oriented modal particles/adverbs will be analyzed as occupying 'Subject-1'. Subject-verb agreement in this case will have occurred between the subject in SpecTP and verb in T. Afterwards, the subject moves to SpecMP ('Subject-1') and the verb moves to C. There are many such examples in our corpus and they all show first-conjunct agreement, as expected given (4).

A methodological problem arises for subject NPs that follow discourse-oriented modal particles/adverbs. This is so because (38) provides a third position for subjects, besides 'Subject-1' and 'Subject-2': the position found within the VP. If one compares (39a) and (39b) (Lash 2014b: 288, ex. 31 ), one clearly sees that subjects can indeed occupy this position.

(39) a. Tānic

danō Brēnainn ìar $=$ sein $\quad$ do $=$ Cill Dara come.PST.3S well Brendan. $\mathrm{N}$ after=DIST to=Kildare $c o=$ Brigit...

to $=$ Brigit.A

'Well, after that Brendan came to Kildare to Brigit...'

(POMIC, LH s. 467) 
b. Tucad trā $\bar{l} a r=\sin$ in $=$ cocad chucai $=$ seom bring.PSS.PST.3S so after=DIST the=fighting to.3SM=3SM $c o=$ dorus in $=$ taige. to $=$ door.A the $=$ house. $G$

'Then, after that the fighting was carried to him to the door of the house.'

(POMIC, FR s. 190)

The subject in (39a) follows a modal particle directly but precedes the temporal adverbial PP. The subject in (39b) follows both a modal particle and the temporal adverbial. For both Definite/proper NPs and indefinite/quantified NPs, Lash (2014b: 288) assumes that the semantic effects associated with 'Subject-2' proper (i.e. SpecTP) will also be found with subjects in this lower position, so in examples that lack a temporal/aspectual adverb, there is no good way of distinguishing between SpecTP and the VP-internal position. In fact, there are many sentences that have subjects whose position could be analyzed as being in either of these two positions. Recall for instance (21d), where the only intervener is a modal particle. Ambiguous sentences such as (21d) will often not be particularly enlightening. If the subject is in SpecTP, agreement works as usual; conjoined NPs would therefore trigger first-conjunct agreement, singular with singular first conjunct and plural with a plural first conjunct. If the subject is in VP-internal position, our proposal is that a default expletive is found in SpecTP, and singular agreement would result. One distinguishing context would be a sentence with a singular verb, a modal particle preceding the subject, a conjoined subject that consists of two plural NPs, and some following material (also in VP) to avoid the possibility that the subject is extraposed (see below). Here, our proposal would be that the conjoined subject must be in VP-internal position. This, however, is not found in our corpus, although we predict it should be possible.

In practice, therefore, only those subjects that we can reasonably ascribe to the lowest position, i.e. to the VP-internal argument position, are in fact 'unusual' from the point of view of the system as we have described it thus far and are in need of an explanation. This is the case for sentences whose subjects are separated from the verb by at least a temporal or aspectual adverb, i.e. (21c), (21e), (21g), (21j). It is these cases specifically that provide the clearest support for our proposal that Early Irish could fill SpecTP with a null 
expletive element. When present, the expletive would prevent movement of the internal argument to SpecTP. (21e) is perhaps most interesting for our proposal because of the presence of an infix on the verb (don $[d] \cdot t i c c$ "comes there') with locative meaning. It is tempting to view this as an overt manifestation of the expletive. One might question why the expletive is apparently overt here, as opposed to any other sentence. We leave this as an open question, but note that this verb is found in a non-main clause context, which may be significant. Embedded clauses in various null subject languages (or partial-null subject languages) require an overt expletive, while main clauses do not. For instance, Icelandic and Yiddish require an expletive in certain embedded clauses (Vikner 1995: 70). Biberauer and van der Wal (2012: 3) note a similar fact for Jamaican Creole, while Ledgeway (2013: 282) mentions that expletives are required much more frequently in embedded clauses in certain null-subject Romance varieties, like Old French, Old Occitan, and Old Umbro-Tuscan.

Another subgroup of sentences in (21) has yet to be discussed. In these sentences, the intervener is neither a modal particle nor a temporal/aspectual adverb. Instead, the intervener is a locative preposition phrase: (21a), (21b), (21f), (21h), (21i), (25k). In these sentences, there are two ways of analyzing the order of verb, locative phrase, and subject, and the agreement between subject and verb. First, since there is no intrinsic problem with topicalizing locative phrases, one might think the phrase is in the 'Subject-1' position. The NP subject would then potentially be in SpecTP, where it would agree normally via first conjunct agreement. A second analysis would be that the locative phrase itself moves to or is merged in SpecTP, i.e. it functions in the same way as the proposed null expletive. This is essentially the analysis mentioned above for Romance.

There is, unfortunately, little evidence that would distinguish between the two possibilities: Locative PP in 'Subject-1' or Locative PP in SpecTP. Example $(21 \mathrm{k})$ is one possibly probative example. It consists of a discourse-oriented modal particle, immorro 'however', followed by a locative PP isin=sruth 'into the stream' followed by an NP subject. Given our assumptions above, represented in (38), this order implies that the PP is not in 'Subject-1' and therefore may be in Subject-2. If so, the NP subject would be lower, in the VP-internal argument position. Example (21g), mentioned above because it has a temporal adverb, is somewhat comparable. In this 
example, a locative PP and 'therein/thereat' precedes the temporal adverb cétamus 'first', which in turn precedes a NP subject. The locative PP could be in 'Subject-1' or 'Subject-2', but the NP, being after the temporal adverb, is certainly in the VP-internal argument position.

We have thus far proposed that either a null locative 'expletive', or an overt locative phrases may occupy SpecTP if the NP subject occupies a VP-internal argument position. We have been careful to use only relatively unambiguous evidence as support for our proposal. It is of course true that the subject positions represented in (38) also account for a much wider range of examples than we have admitted above. This includes the ambiguous examples discarded in the course of our discussion as well as passive examples like (18a) and (27a), which lack an intervener. Here, the claim would be that, although the position of the subject in the linear string is ambiguous, the subject in such sentences does in fact remain in its base position, while the SpecTP position is occupied by the expletive. ${ }^{22}$ This claim weakens the proposal somewhat, but it is undoubtedly the case that subjects in passives can in general occur in the VP-internal argument position. We have seen this above in (39b) and this is further exemplified in (40).
a. $D u \cdot b e r<r>\quad f u=d i \quad a=n d l i g e d=s a$
$\mathrm{PV} \cdot$ give.PSS.3S under=two.D the $=$ expression. $\mathrm{N}=\mathrm{PROX}$ isind $=$ salm.
in-the $=$ psalm.D
'This expression is put twice in the psalm.' (M1. 77 11 )

b. Do-mm·árfas

$$
\bar{l} a r=\sin \quad \text { ina }=\text { oible tened }
$$

PV-1S·PRF.appear.PSS.PST.3S after=DIST the $=$ sparks.N fire.G asin $=$ mórchiaich $=\sin$.

from-the $=$ great.mist. $D=$ DIST

'After that the sparks of fire appeared (lit. were shown) to me from out of that great mist.' $\left(T B C^{I}, 1.3560\right)$

Both subjects in (40) appear after an aspectual (40a) or temporal (40b) adverbial. The VP-internal argument position is a possible subject position at all periods. (39b) is from a tenth-century text; (40a) is an eighth/ninth-century gloss, and (40b) is from an eighth-century text that is preserved in manuscripts 
from the eleventh century and later, and therefore subject to potential revision. All this being so, there is nothing in principle to prevent an analysis whereby a NP-subject with no interveners is ascribed to the lowest possible position in the clause.

The upshot of our argument is that we have derived a set of potential unaccusative diagnostics for Early Irish. The main one we have argued for is a variant of the There-Insertion diagnostic. Burzio $(1981,1986)$ originated a long line of research into the status of There-Insertion in English that showed that it is only grammatical with unaccusative verbs. This is so because unaccusative verbs allow the semantic subject to remain in its base position, the internal argument position, while the expletive there is inserted in the canonical subject position (SpecTP). This explains the difference in grammaticality in (41a-c).

a.

At that moment, there arrived on the scene two police cars, full of riot police.

b.

And, so far as I know, there were, in the course of events, several demonstrators arrested by police.

c.

*And, there shot, so they say, the police four demonstrators.

The other diagnostic we have argued for is also a well-known one. It is the Locative Inversion (LI) Diagnostic. LI constructions are very similar to There-Insertion constructions and have typically been viewed as having substantially similar properties. LI is grammatical only for unaccusative or passive verbs. ${ }^{23} \mathrm{LI}$ constructions show non-canonical order of the verb and the constituents governed by it. In English, the order is [PP V NP], as in (42). A typical analysis of this structure is that the NP is in the internal argument position while the PP is placed in a preverbal position, such as SpecTP. 
(42) $\left[_{\mathrm{PP}}\right.$ Out of the house $]$ came $\left[_{\mathrm{NP}}\right.$ a tiny old lady].

Mendikoetxea 2006: ex. 1a)

The LI and There-Insertion diagnostics lead us to expect only unaccusative and passive verbs in Early Irish sentences with Locative PP or temporal/ aspectual interveners and a verb showing singular agreement with a conjoined subject, if these constructions can be reduced to the presence of either a null there-type expletive or a locative PP in SpecTP. The evidence in our corpus supports this. But, of course, further research will be necessary in order to confirm it. ${ }^{24}$

Although we have used English above as a point of comparison, there are at least two crucial differences between English and Early Irish. Unlike English, the Early-Irish expletive had default singular number, at least descriptively. ${ }^{25}$ This accounts for the singular number of the verb even when the associates are plural. Another difference from English is the fact that Early Irish did not show a definiteness effect, whereby the associate in expletive constructions is limited to being an indefinite or quantified expression. In fact, most of the examples in (21) have definite subjects. There are nine examples with definite subjects (21a, 21b, 21c, 21f, 21g, 21h, 21i, $21 \mathrm{j}, 21 \mathrm{k})$ compared to only two with indefinite subjects $(21 \mathrm{~d}, 21 \mathrm{e})$. This situation is not at all unique. Sheehan (2006: ch.3, 2016: 28-9) points out that in null-subject Romance languages (Spanish, Italian, European Portuguese) definiteness effects are not found in clauses in which locative inversion has applied or in which null locative expletives occupy the subject position. The behavior of VP-internal subjects in Early Irish is quite distinct from such subjects in Modern Irish, at least in existential clauses where McCloskey (2014) shows that definiteness effects are found (43). We take this as strong evidence that (43) lacks a locative expletive, while at least some of the Early-Irish sentences in (21) have a locative expletive or locative inversion, and hence no definiteness effect.

(43) a. Beidh be $\left.{ }_{\mathrm{FUT}}\right]$ $\begin{array}{ll}\text { na } & \text { Dilseoiri } \\ \text { the } & \text { Loyalists }\end{array}$ igcónaí

always ann. in-it 


$\begin{array}{lllll}\text { b. }{ }^{*} \text { Beidh } & \text { i gcónai } & n a & \text { Dílseoiri } & \text { ann. } \\ \text { be }_{[\mathrm{FuT}]} & \text { always } & \text { the Loyalists } & \text { in-it } \\ \text { 'There will always be the Loyalists.' } & \text { (McCloskey 2014: ex. 69) }\end{array}$

Sheehan does not deal with agreement effects in the following languages, but there are data somewhat comparable to Early Irish in other null-subject Romance languages. Consider (44) from the North-Central Marche dialect of Urbino. (44a) shows full agreement with a pre-verbal subject; (44b) shows partial agreement (in Person) with a post-verbal agreement. Similar dialects of the North-Central Marche area apparently do not show straightforward definiteness effects along with optional full or partial agreement (see Manzini and Savoia 2002: 188-90 for discussion).

(44) a. ki bur'dei veyne 'ds:p.

those children come afterward

'Those children come afterward.'

b. 'ds:p viey ki bur'dei. afterward comes those children (modified from Manzini and Savoia 2002: 172, ex. 20)

Above, we have concentrated on examples that conflicted with the straightforward rules of BST, summarised in (4). There are also many examples that do not conflict with BST, but nonetheless need to be clarified, given the system we have developed here. The examples in question have conjoined subjects with plural agreement and an intervener, such as (45).
a. Lotar
didiu
in $=$ Gaileóin
na=Muimnech.
go.PST.3P moreover the $=$ Gaileóin(pl).N and the=Munstermen.N
'Moreover, the Leinstermen and the Munstermen went.' $\left(T B C^{I}\right.$ 1. 4108) 
b. $\bar{O} \quad$ ró=sinset

$a=$ läma

chuci $\quad[$ in $=$ drai

after $\mathrm{PRF}=$ stretch.PST.3P their=hands.A to.3SM the $=$ druid.N and

in $=$ chumal],

$n i=$ ro $=$ artraig

in =tene.

the=slave.woman. $\mathrm{N} \quad \mathrm{NEG}=\mathrm{PRF}=$ appear.PST.3S the $=$ fire. $\mathrm{N}$

'After the druid and the slave woman stretched their hands to it, the fire disappeared.' [lit. 'did not appear'] ( $B B r 62$ b p. 56.35)

(45a) is straightforward. Because the conjoined subject consists of two plural nouns following a modal particle, we analyze this as simple first-conjunct agreement with the subject in 'Subject-2', i.e. SpecTP. (45b) shows plural agreement with two conjoined singular NPs in which there are several intervening elements. This is expected according to the BST rules. However, according to the system we have developed above, there is no way to account for the plural agreement and the position of the subject. Consider the following account of the word order of this sentence. First, the object could be in 'Subject-1', if it is topicalized in context. If this were so, then the locative PP (chuci 'to it') would need to be in SpecTP (Locative Inversion) and the subject in its base position, the internal argument position. Various considerations speak against this. First, the verb is transitive and the subject therefore should not be grammatical in internal-argument position. Rather it is the object that is first merged in this position. The subject itself should merge in the external-argument position. Secondly, even if the subject were acceptable in the internal-argument position and locative inversion had placed the PP in SpecTP, we would expect singular agreement, as discussed above.

To account for such examples, we suggest that the apparent subject is in fact a right-dislocated phrase in the specifier of $\mathrm{CP}$, while the verb agrees with its true subject, which is a plural null pronominal pro in SpecTP. The other elements (or at least the PP) remain within the VP. Essentially, this is the same as the well-known analysis of right-dislocation in Italian (see, for instance, Cardinaletti 1997). We illustrate this suggestion in (46). ${ }^{26}$ 


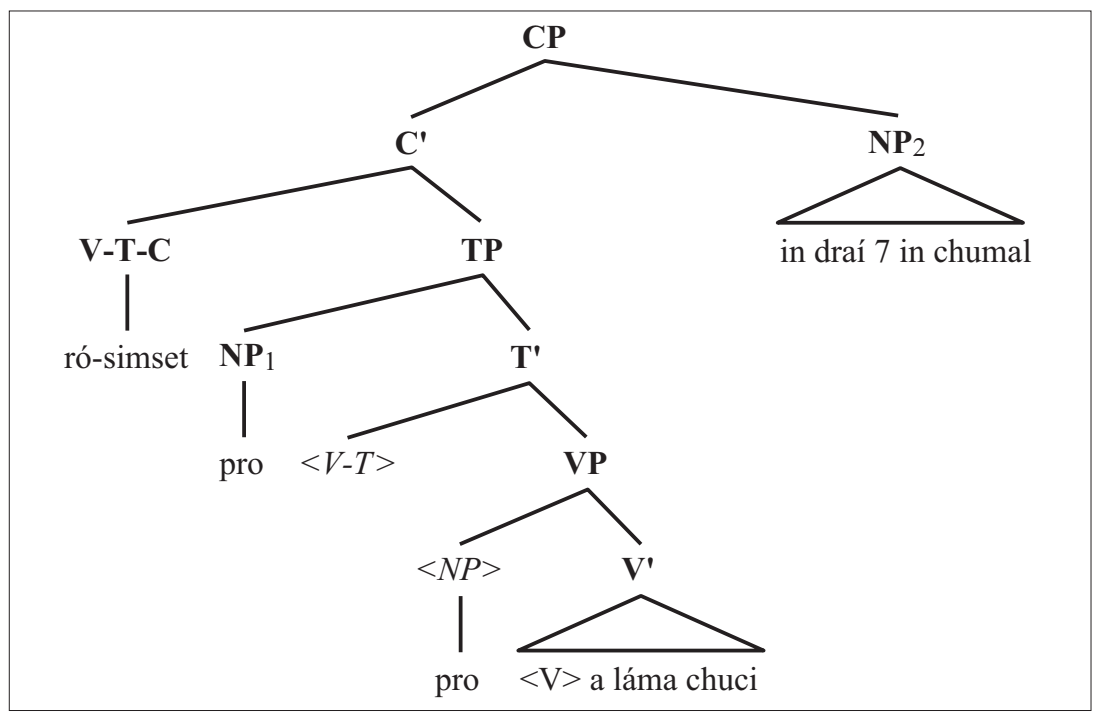

The main feature of (46) is that the subject is in the absolute final position in its clause and the verb has plural agreement, no matter what the grammatical number of the conjoined NPs is. This means that concord between the pronominal and the subject is purely semantic. Since two (or more) conjoined NPs will most likely be construed as semantically plural, we should always find a plural pronominal and therefore plural agreement here. Other formal and semantic features of this construction cannot be analyzed further here, for more information, see Lash (2014b: 278-80) and Mac Gilla Easpaig (1980).

Observe that, given the assumptions outlined here, there is nothing to distinguish between the specific examples discussed here, i.e. (45a) and (45b), since the subjects in both are in the absolute final position. This is not a problem for the analysis, since it is always possible for two identical surface strings to have different underlying structures. However, right-dislocation can in principle be distinguished from sentences with absolute final subjects in SpecTP where the verb is plural. The distinguishing case that can only be right-dislocation in these terms would be a sentence with a plural verb whose 
absolute final subject is preceded by a temporal/aspectual adverb or a complement (object or PP), if there is some indication that the complement has not raised out of VP.

Subjects in right-dislocation can also be distinguished from subjects in the internal-argument position in certain cases because only unaccusative verbs or passives should allow subjects in the latter position. Therefore conjoined singular subjects in absolute final position, if SpecTP can be ruled out, will always show plural agreement with transitive verbs and will fluctuate between singular and plural for intransitive verbs. This is so because the subject in transitive verbs will be in right-dislocation (where only plural agreement is found) while the subject of unaccusatives/passives could either be in right-dislocation or in internal-subject position where agreement is with a default singular expletive, as argued above.

A final two examples also conform to BST, but are anomalous from the point of the view of the proposal in this paper. These examples (FR s.66, $\mathrm{PH}$ 1. 640) have a plural verb with a medial subject that is plausibly in SpecTP and whose first conjunct is singular (47). These are unexpected given our argument thus far, although they probably can be assimilated to examples involving apposition like (18b) and (19).

No-s-marbtais immorro Doilin ocus Daithlend cach=toffond
PTC-3P·kill.IMPF.3P however PN.N and PN.N every=hunt.A
ar=úair ar- $a=$ mbélaib=side...
'by=turn.A' by-their=lips.D=ANAPHOR

'Doílín and Daithlend, however, during every hunt, used to kill them by turn in front of them.' (FR s.66)

\section{Conclusion}

The goals of this paper have been twofold: to determine the descriptive rules governing the syntax of verbal agreement with coordinated subjects and to offer a theoretical account of these facts. The starting point for this investigation was the BST statement of agreement rules for coordinated subjects in Classical Modern Irish. Those rules, summarized in (4) and repeated here are: 
(48) a. If the verb and the first conjunct are adjacent, a first-conjunct analysis suffices.

b. If the verb and subjects are separated, the verb is plural.

These rules account for the data of Classical Modern Irish and indeed much of the data from Old and Middle Irish. Nonetheless, it is clear that there is a small number of examples from Early Irish for which these rules are inadequate. For these examples, both the position of subjects relative to the verb as well as the transitivity of the verb must be considered in order to account for the data adequately. Seen descriptively, the rules for Early Irish are the following:

(49) a. If the verb and subjects are structurally adjacent (not the same as linearly adjacent), the verb agrees with the first conjunct (partial agreement).

b. If the verb and subjects are not structurally adjacent, a transitive verb shows plural agreement (full agreement), while an intransitive or passive (i.e. non-transitive) verb may be plural or singular.

Alternation between full and partial agreement based on the relative position of the verb and subjects is well documented cross-linguistically (see section 4.1 above). The twist added in Early Irish is that non-transitive verbs have variable agreement.

While corpus data frequently limits the types of syntactic tests available to the researcher, we have proposed that non-transitive verbs may behave just like transitives and have partial agreement or full agreement, depending on whether there is intervening material between the verb and subject. On the other hand, non-transitive verbs may also be found with singular agreement regardless of their number and position. This singular agreement, we argue, is due to the presence of a null locative expletive with default $3 \mathrm{sg}$. number.

The idea that Early Irish had a null expletive is somewhat surprising, since it assumes that the language was subject to the EPP, unlike Modern Irish. Nonetheless, there are a number of facts suggesting that this idea is indeed correct. As Lash (2014b) has observed, three separate sets of adverbs/PPs allow us to distinguish three different subject positions. Two of these are 
available to the subjects of all verbs: a higher position (Subject-1), the specifier of a modal phrase immediately below CP; and a lower position (Subject-2), which is apparently SpecTP. For unaccusatives and passives, it appears that there is also a third subject position: the VP-internal one. Most subjects, i.e. the ones in one of the higher subject positions have first conjunct agreement with their verbs by being in or having moved through SpecTP. We argue that exceptions to first conjunct agreement for unaccusative verbs occur because the subject has remained VP internal. The higher subject position is then filled with a locative expletive or a locative adverbial/PP. It is noteworthy that 'low' subjects are significantly associated with intransitive verbs, not transitives (Lash 2015; see also footnote 24 above). Further, locatival interveners are well-represented with unaccusative verbs with the 'exceptional' agreement pattern of singular verb with conjoined subjects. While probative examples are very rare (though see $(21 \mathrm{~g})$ and $(21 \mathrm{k})$ ), locatives and expletives frequently fill the same slot cross-linguistically, and it is thus plausible that Early Irish had a locatival expletive.

In sum we distinguish the following positions and elements that fill them (50).

(50) a. 'Subject-1' (Topic/Wide Scope Indefinite): may be filled by any XP provided it fulfills the semantic/pragmatic conditions.

b. SpecTP ('Subject-2'): may be filled by pro, $\operatorname{Loc}_{\text {expl}}, \operatorname{Loc}_{\mathrm{PP}}$, NP.

c. VP-internal argument position: may be filled by NP argument of unaccusatives/passives.

d. Right-Dislocated Position (SpecCP): may be filled by NP. cross-referenced with pro in SpecTP.

e. pro in SpecTP may have an appositive NP.

Our proposal that Early Irish had the EPP gives rise to another related hypothesis that we could not explore in full in this paper. This hypothesis has to do with the set of unaccusative verbs in Modern Irish that McCloskey (1996) called 'salient unaccusatives'. These verbs have the properties in (51).

(51) a. They s-select a single oblique internal 'argument' marked by a preposition. 

b. They lack a structural subject.
c. They are semantically unaccusative (involuntary change of state, 'succeed', 'fail', 'quarrel').
d. The oblique 'argument' remains internal and cannot raise.
e. The prepositions are not case-marking particles.

These properties are exemplified in (52). The oblique internal 'argument' of the salient unaccusative (52a) remains low while the non-oblique argument of a normal unaccusative (52b) can raise.
a. Bhí
$a g$
$\left[_{\mathrm{VP}}\right.$ neartú ar a
ghlór].
be.PST PROG strengthen on his ${ }^{\mathrm{LEN}}$ voice

'His voice was strengthening.' (McCloskey 1996: 248, ex.15a)

b. Bhi $\quad\left[\begin{array}{ll}\text { a } & \text { ghlór }\end{array}\right]_{\mathrm{i}} \quad$ ag $\quad\left[_{\mathrm{VP}}\right.$ neartú $<$ a ghlór $\left.>_{\mathrm{i}}\right]$.

be.PST his ${ }^{\mathrm{LEN}}$ voice PROG strengthen

'His voice was strengthening.'

A key feature of these verbs is (51d). McCloskey (1996: 260) puts forward the proposal that the 'argument' of these verbs cannot raise because there is no position for the argument to raise to, i.e. there is no EPP in Modern Irish. Furthermore, he argues that languages that do have an EPP and a 'pleonastic element' (an expletive) still cannot license salient unaccusatives. This is so because 'pleonastic elements' cannot be linked with a PP. Given our proposal that Early Irish in fact did have the EPP which licensed an expletive in SpecTP, we might be led to suspect that Early Irish does not have salient unaccusatives. We express this as (53).

'Pure' Salient Unaccusatives with only one XP within VP (i.e. the XP fulfilling 51a) are non-existent in Early Irish.

In fact, the class of salient-unaccusative verbs does indeed appear to be almost vanishingly rare, or even non-existant in at least Old Irish. A detailed survey of impersonal verbs and verbs whose subjects are non-nominative lies outside the scope of this paper, however, in order to ascertain whether or not salient unaccusatives existed in earlier stages of Irish, the electronic Dictionary of 
the Irish Language (eDIL) was used as a resource in two test studies. In the first study, the Early-Irish etymological equivalents to Modern-Irish salient unaccusatives as well as all those verbs whose meanings correspond closely to meanings of Modern-Irish salient unaccusatives were examined. The list of Modern-Irish salient unaccusatives found in McCloskey (1996) was used as a basis for this study. The investigation of eDIL resulted in a list of 124 verbs. Of this list, only eleven were found in an apparent salient-unaccusative construction. These verbs are listed here: ${ }^{27}$

(54) a. ásaid for, 'increases'

b. do.eipen ar, 'fails'

c. do'maid do, 'breaks forth, bursts'

d. éirgid eter, 'quarrels'

e. lúatha(ig)id ar, 'hurries, makes haste, goes faster'

f. maidid de, 'is routed, puts to flight, flees, rushes'

g. methaid for, 'fails, comes short'

h. téit ar, 'fails, is exhausted'

i. téit de, 'fails'

j. téit oc, 'prevails, succeeds'

k. tromaigid ar, 'intensifies'

The salient unaccusative constructions with these verbs are all found in Middle or Early Modern Irish, except for (54f) and (54g), which are found in Old Irish texts. We will discuss (54g) below. Note, however, that (54f) and the closely related verb found in (54c) are hardly obvious examples of salient unaccusative for at least two reasons. On the one hand, the evidence from (55a), which contains a suffixed pronoun, suggests that the verb may be reflexive. If so, the subject may be understood as cath 'battle' or the like. On the other hand, both sentences in (55) (and others containing this verb) can be interpreted as partitive constructions with a null quantifier corresponding to $n i$, like the sentence discussed above in (11).
a. Mutt- $i$
dont $=$ slóg
immi
$d i=$ cach $=l e i t h$.

break.3S-3SN from.the=host.D around.3S from=every=side.D

'The host rushes about him from every side.' $\left(T B C^{I} 1.1679-80\right)^{28}$ 
b. Maidid danō di-a=muntir=seom for $=t e[i] c h e d$.

break.3S so from-his=followers. $D=3 \mathrm{SM}$ on=flee.VN.D

'So, his followers took to flight.'

$\left(T B C^{l} 1.1680-1\right)$

For the second case study, we searched the eDIL for the tag 'impers.' Among the ninety-nine verbs that are tagged as 'impers.', there are twelve that occur in possible salient-unaccusative constructions. These are listed in (56), except for the three (ásaid ar, tromaigid ar, methaid for), which were also found in the first case study. For each verb in (56), the example in the eDIL consists of an active verb, lacking a clear nominative subject, in which most of the noun phrases are embedded within prepositional phrases.

(56) a. con'ricc do/eter, 'quarrels, fights'

b. do'tét do, 'sets out, comes out'

c. fordergaid for, 'gets wounded'

d. gleccaid do, 'quarrels, struggles, wrestles'

e. lonnaigid [ir] imm, 'becomes enraged'

f. madmaid ar, 'is routed, puts to flight'

g. ro:saig do, 'reaches'

h. saidid do, 'remains'

i. sochtaid for, 'to fall silent'

As in the first study, most of these are found in Middle Irish or Modern Irish texts. ${ }^{29}$ Both searches turned up examples of the verb methaid, which occur in Old Irish texts (57). ${ }^{30}$ Additionally, in the second search another verb, do tét, was found. This too occurs in Old Irish texts (58a-b).

... mani $=$ =ro $=$ metha fair forsin $=$ cèle.

unless. $\mathrm{NEG}=\mathrm{PRF}=$ fail. $3 \mathrm{~S}$ on. $3 \mathrm{~S}$ on.the $=$ tenant

'...provided the tenant has not failed in any duty to him.'

(Cáin Aicillne; CIH 486.10, Thurneysen 1925: 363, §23) 


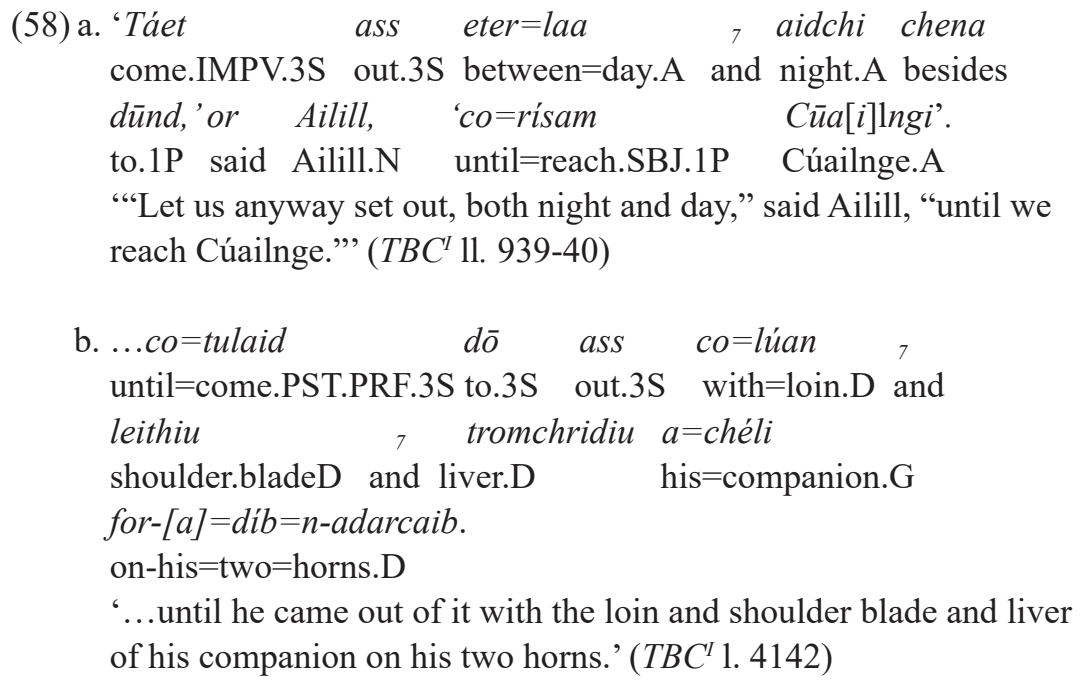

These are in fact entirely ambiguous with regard to the positioning of the various elements. Each contains what might be termed a locative PP: fair (57), ass (58a-b). Given our proposal that Early Irish exhibited Locative Inversion, these might be analyzed similarly as well. Note, in particular, that in (58a) the locative preposition appears before a temporal adverbial phrase headed by eter; thus it has to have moved out of VP. Of course, there is no direct evidence that the locative PPs occupy SpecTP ('Subject-2'); they could also be topics in 'Subject-1' instead. The contrast in the position of the notional subject chena dūnd 'us anyway' in (58a) and $d \bar{o}$ in (58b) is intriguing. It can be interpreted as follows. In (58a), the VP-internal position is reserved for narrow focus (as in Romance languages, see Sheehan 2006 and 2016 for examples). In (58b), the PP raises to 'Subject-1' as a topic. Under this analysis, neither example tells us much about SpecTP, except if one assumes that the locative in both occupies this position. Because the evidence for Salient Unaccusatives is so meager and ambiguous for Old Irish, and because all of the examples also contain a locative PP, we consider that there is at least a possibility for the hypothesis in (53) to be true.

We therefore preliminarily conclude that in Old Irish so-called 'salient unaccusatives' are very rare. This is so for three reasons. First, they may be possible only if some item, such as a locative expletive or locative PP, was 
present in the clause, such that that item can fulfill the EPP through Locative Inversion to 'There-Insertion'. Second, many examples will be ambiguous in the same way as (57-8), thus the basis for analysis is very restricted. Finally, it must always be borne in mind that absence of a phenomenon in a corpus language could just be a textual accident. However, it does seem that the small number of unambiguous examples in even Middle Irish is not due just to chance.

A follow-up project would be to focus specifically on the history of the salient-unaccusative construction using an adequate corpus-based and statistical approach to further our understanding of the contexts for its innovation and the time-scale of its diffusion. The project would need to explore the various pseudo-salient unaccusative verbs with meanings like 'fight' or 'quarrel', such as ásaid, con-ricc, gleccaid, maidid that mark at least one argument with a preposition but may be analysed as having a null subject corresponding to a word like cath 'battle', or similar (see 55 above). A related problem is the rise of impersonal reciprocal constructions in which the verb takes the prefix $i m m a^{N}$ and at least one argument is marked with a preposition (for a collection, see O'Brien 1938).

We have tried to place the Early-Irish data in a comparative context, by citing studies concerning Dutch, Arabic, Polish, and various Romance languages, amongst others. In addition to the issue of salient unaccusative, future research should also concentrate on exploring expletive constructions in Romance and Early Irish with the aim determining the full distribution of null subjects in Irish, the history of verb-subject agreement in Locative Inversion or 'There-Insertion' contexts, and the extent of Early Irish's apparent 'immunity' to definiteness effects.

The present study highlights the usefulness of large-scale electronic databases that are tailor-made for research into the linguistic structure of Early Irish. We have used corpora such as the Parsed Old and Middle Irish Corpus (Lash 2014a), the Milan Glosses Database (Griffith 2013), and the Priscian Glosses Database (Bauer 2015), in order to obtain much of the data in this paper. Although these resources are all helpful for linguistic research, they are not all equally as useful for specifically syntactic studies, such as the present paper. Parsed corpora such as Lash (2014a) take precedence over purely part-of-speech or morphologically tagged corpora, such as Griffith (2013) and Bauer (2015). Both types of corpora, of course, are much easier 
to work with for such purposes than untagged corpora like the Early Irish Glossaries Database (Russell, Arbuthnot, and Morán 2010), the electronic Dictionary of the Irish Language (eDIL), and the CELT database hosted at University College Cork. Future work on syntax such as the projects outlined above would benefit from the addition of syntactic parsing to existing databases, and the expansion of such databases to include further (previously edited) texts.

Of course, the fact that there are few resources for researching Early Irish is not the only cause of the difficulty in reaching an adequate description. Our results also show the complexity of such a task, given the time scale covered by the data (c.600-1200). With regard to the specific problems discussed above, the overall picture seems to be that a grammar with the EPP and lacking the salient-unaccusative construction was in general stable up until some time in the Middle-Irish period, that is, perhaps in the twelfth century.

As Isaac (2003) wrote, a definitive description of the synchronic and diachronic syntax of Early Irish remains to be written. This paper is one small contribution towards achieving that goal. Given the extent of the material, there is much room for further research, which we believe would be most beneficially undertaken using a formal and quantitative approach, as in this paper. Moreover, the results of this paper underline the importance of examining together seemingly unrelated phenomena, such as verb-subject agreement with coordinate subjects, word order, and the presence of salient unaccusatives. This kind of depth can often be achieved only with the kind of formal approach adopted here.

\section{Appendix: List of Sources and Coordinate Subject Examples}

\section{List of Primary Sources (for Coordinate Subjects)}

Aislinge Maic Con Glinne (AMC, POMIC)

Additamenta to the Book of Armagh (ABA, POMIC)

Bechbretha (BB, Charles-Edwards and Kelly 1983)

Old Irish Bethu Brigte (OIBB, POMIC)

[Homily on] Betha Brigte (BBr, Stokes 1877) 
Brislech Mór Maige Muirthemni (BMMM, Kimpton 2009)

Crith Gablach (CG, Binchy 1941)

Cambrai Homily (CH, POMIC)

Compert Mongán (and three other early Mongán tales) (CM,

White 2006)

Corpus Iuris Hibernici (CIH, Binchy 1978)

Fled Bricrenn (FB, Mac Cana and Slotkin 2014)

Fingal Rónáin (FR, POMIC)

Prefaces to the Liber Hymnorum (LH, POMIC)

Loinges mac nDúil Dermait (LMDD, Hollo 2005)

Milan Glosses (Ml., Griffith 2013)

Monastery of Tallaght (MT, POMIC)

Old Irish Homily (OIH, POMIC)

Passions and the Homilies from the Leabhar Breac (excerpt) (PH,

Atkinson 1887)

Pseudo-Historical Prologue to the Senchas Már (PHPSM, Carey 1994)

Sankt Gallen Glosses (Sg., Bauer 2015)

Recension I of the Táin Bó Cúailnge (TBC', O'Rahilly 1976)

Táin Bó Froích (TBF, Meid 2015)

The Three Drinking Horns of Cormac mac Airt (TDH, POMIC)

Talland Étair (TE, Ó Domhnaill 2005)

Treatise on the Psalter (TP, POMIC)

Table of Penitential Commutations (TPC, POMIC)

Vision of Laisrén (VL, POMIC)

Würzburg Glosses (Wb., Stokes \& Strachan 1901)

West Munster Synod (WMS, POMIC)

\section{List of Examples [excluded examples underlined] ${ }^{31}$}

\section{A. $\mathbf{V S}(\mathrm{X})$}

1. V-sg.

a. Sg.+Sg. (128, excl. 17)

ABA s.1, ABA s.19, AMC s.10, AMC s.113, AMC s.148, AMC s.155, AMC s.243, AMC s.320, AMC s.418a rell dermáir , nertlīa, AMC s.458, $\underline{\mathrm{AMC}}$ s.539b do üasal nó d'ísel, AMC s.766, AMC s.788, $B B \S 11, B B \S 45, B B \S 46$, $B B \S 49, B B r$ 61b-62a p. 52.11, $B B r$ 62a p. 52.32, $B B r$ 62a p. $54.8, \underline{B B r} 62 \mathrm{a}$ 
p. $54.11, B B r 63$ a p. $62.5, B B r 63$ a p. $62.28, B B r 63$ a p. $62.38, B B r 65$ a p. 76.27, $B B r 65$ a p. 76.32, $C G \S 6-7, C G \S 9, C G \S 13$ a a airechas, a eneclann, $C G \S 25, C M 2 \S 6, \underline{C M 2} \S 9, \underline{C M 4} 44, F B$ 1. 82, FB 1. 172, FB 1. 179, FB 1. 334, $F B 1.448, F B$ 1. 459, $F B$ 1. 474, FB 1. 481, FB 1. 920, FB 1. 1505, FR s.62, LH s.258, LH s.284, LH s.515, LH s.571, LMDD §16, LMDD §17, LMDD

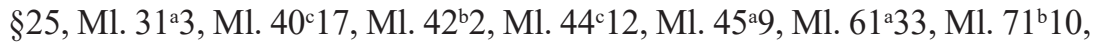
M1. 91`1, Ml. 118`5, Ml. 124c15, MT s.5, MT s.61, MT s.174, MT s.249, MT s.262, MT s.345, MT s.349, MT s.398, MT s.457, MT s.509b nert nā brīg, MT s.513, OIBB s.11, OIBB s.20, OIBB s.100, OIBB s.111, OIBB s.353, OIBB s.490, OIBB s.610, OIH s.31, $P H 1.10, P H 1.176, P H 1.222, P H 1.337$, $P H$ 1. 787, $P H$ 1. 850, $P H$ 1. 1105, $P H$ 1. 1475, $P H$ 1. 1627, $P H$ 1. 2031a fechtnaige shuthain 7 fäilte cen crich, aireru oibne, $P H 1.2031 \mathrm{~b}$ téidm no toirsi no bás, PH 1. 2339, PH 1. 2409, PH 1. 2411, PHPSM §3, PHPSM §4,

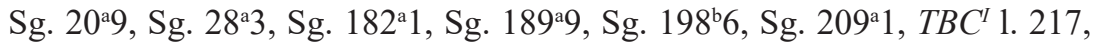
$T B C^{I}$ 1. 230, $T B C^{\underline{I}} 1.476, T B C^{I} 1.484, T B C^{\underline{I}} 1.653, T B C^{I} 1.963, T B C^{I} 1.971$, $T B C^{I} 1.1006, T B C^{\underline{I}} 1.1623, T B C^{\underline{I}} 1.1746, T B C^{I} 1.2079, T B C^{I} 1.2487, T B C^{\underline{I}} 1$. $\underline{2532}, T B C^{I} 1.3089, T B C^{I} 1.3512, T B C^{I} 1.3515, \underline{T B F} \S 13$, TP s. 125, TP s. 158, TP s. 225, TP s. 227, TP s. 228 , TP s. $231, \underline{\text { Wb. } 14} \underline{\text { c }} 11$, WMS s. 9 , WMS s. 23

b. Sg. + Pl. (10, excl. 5)

AMC s. $369, B B r 63$ b p. $63.32, B B r 64$ a p. $66.1, B B r 64$ b p. $74.19, \underline{B B r} 65 \mathrm{~b}$ p. $82.6, F B$ 1. 327 , OIBB s. $348, T B C^{I} 1.986, \underline{T B C^{I}} 1.3145$, TDH s. 6

c. Pl. + Pl. (7, excl. 0)

AMC s. 157, AMC s. 192, AMC s. 216, AMC s. 281, AMC s. 577, TDH s. 2 , TDH s. 8

2. V-pl

a. Sg. + Sg. (4, excl. 3)

$\underline{\text { ABA s. } 66}, \underline{B B r} 64$ a p. $70.8, P H 1.1881, \underline{T B F \S 8}$

b. Pl. + Pl. (41, excl. 4)

AMC s. 21, AMC s. 101, AMC s. 283, AMC s. 408, AMC s. 418b slega 7 semmunna, AMC s. 418c renda fäebra, AMC s. 423, AMC s. 539a senchaide ${ }_{7}$ senóri ${ }_{7}$ libair Chorccaige, AMC s. 719, BBr 62a p. 54.5, BBr 64a p. 68.33, 
$B B r$ 65a p. 78.1, $B B r$ 66a p. 86.1, $C G$ §34, $C M 2$ §14, LH s. 98 , Ml. $36^{\mathrm{d}} 16$,

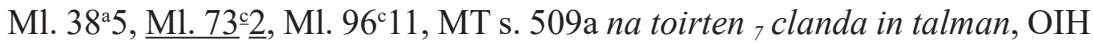
s. $78, P H$ 1. 92, PH 1. 1296, PHPSM §11, Sg. 5 15 , Sg. $10^{\text {a }} 8$, Sg. $28^{\mathrm{a}} 4, \mathrm{Sg}$. $30^{\mathrm{b}} 12, T B C^{I} 1.22, T B C^{I} 1.456, T B C^{I} 1.2249 \mathrm{a}$ a thraigthe, a luirgne, a glún, $T B C^{I} 1.2249 \mathrm{~b}$ a sála , a orcni, a escata, $T B C^{I} 1.3433$, TP s. 52, TP s. 157, TPC s. 8a fingala , duineorcni ${ }_{7}$ duinetáidi, TPC s. 8b diberggae 7 druithdechta ${ }_{7}$ cantechda, TPC s. 8c adultracha ${ }_{7}$ cuiligi ${ }_{7}$ eithech ${ }_{7}$ eres ${ }_{7}$ tairmtechtae graid, VL s. 34, Wb. $8^{\text {b3 }}$

c. Pl. + Sg. $(4$, excl. 2$)$

AMC s. $713, B B r 64 b$ p. $72.11, \underline{C G \S 13 \mathrm{~b}} \underline{\underline{30}}, \underline{T B C} \underline{\underline{\underline{I}}} \underline{\underline{1035}}$

3. V-?, Sg. + Sg. (2, excl. 2)

$\underline{\text { Sg. } 11^{\mathrm{a}}} \underline{\underline{W}}, \underline{\text { Wb. } 33^{\mathrm{b}}} \underline{19}$

\section{B. $\operatorname{VXS}(X)$}

1. V-sg.

a. Sg. + Sg. (30, excl. 16)

$B B r$ 62a p. $54.35, B B r$ 62a p. $56.25, B B r$ 63a p. $60.39, B B r 63$ a p. $62.41, B B r$ 65 a p. $78.29, B M M M \S 27$, CH s. $22, \underline{F B} 1.67, F B 1.79$, LH s. 66, LMDD §29,

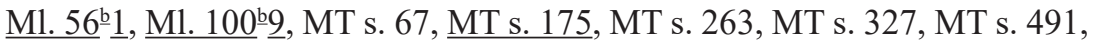
MT s. 493, OIH s. $3, T B C^{ \pm} 1.151, T B C^{\underline{I}} 1.371, T B C^{I} 1.462, T B C^{I} 1.548, T B C^{I}$ 1. 1734, $T B C^{I} 1.2575, T E 1.113, \underline{T E 11.179-80}, \underline{T E 1.220}$, TPC s. 52

b. Pl. + Pl. (1, excl. 1)

WMS s. 39

2. V-pl.

a. Sg. + Sg. (10, excl. 3)

$B B r 62$ b p. $56.35, \underline{B B r} 62$ b p. $58.25, \underline{B B r} 63$ b p. 68.15 , FR s. 66 , MT s. 621, $T B C^{I} 1.333, \underline{T B C^{I}} \underline{1.926}, T B C^{I} 1.1622, T B F \S 15$, WMS s. 2

b. Sg. + Pl. (2, excl. 0)

FB 1. 144, PH 1. 640 
c. Pl. + Pl., (4, excl. 0)

$B B r 61$ b p. 52.9, OIH s. 2, Sg. $44^{\text {b } 3, ~} T B C^{I} 1.4108$

d. Pl. + Sg. (2, excl. 2)

$\underline{C M 2} \$ 11, \underline{T B F \S 24}$

3. V-?, Sg. + Sg. (1, excl 1)

FB 1. 187 


\section{Notes}

1 The research for this article was completed with funding provided by: the ZIFMarie Curie two-year fellowship (Universität Konstanz), Zukunftskolleg (U. Konstanz) Co-Funding, and the Chronologicon Hibernicum (Maynooth University, ERC Consolidator Grant 2015, H2020 \#647351). We would like to thank two anonymous referees as well as members of the Language Structure: Variation and Change research group at Utrecht University for valuable comments on this work.

2 Examples cited are taken as they stand in the edition of the text, but we have introduced a small amount of standardization for expository purposes: consistent indication of clitics, word boundaries, macrons for length, etc. Those examples that form part of our core corpus of verbs with coordinate subjects are cited using the abbreviation mentioned in appendix 1. Examples from The Parsed Old and Middle Irish Corpus (POMIC) are cited with the word POMIC followed by the abbreviation of the text name and the sentence number in that corpus. Other texts are cited with the full name of the text, followed by the editor's name and the date of the edition (if from edited texts). Texts from the Corpus Iuris Hibernici $(\mathrm{CIH})$ also include the $\mathrm{CIH}$ page and line number. Translations are taken from the cited editions, sometimes with minor changes. More significant departures in interpretation or translation are explicitly noted.

3 For this translation of sunnradh, see McKenna (1944 [1979]: 258, ex.29-38).

4 A reviewer points out that preceding the BST text quoted in (3) mention is made of the following type of sentence:

\section{i. Do g(h)on siad Domhn(all) agus Tadhg me.}

'Domhnall and Tadhg, they hit me.'

We would classify this as an instance in which the conjoined noun phrase Domhnall agus Tadhg is appositive to the true subject, siad. While appositional subjects appear in the Early Irish data, this particular structure is impossible in Early Irish because the verb must always agree with a pronominal in subject position, whether the pronominal is overt or covert. In Modern Irish, however, overt pronominals require the analytic form. For an influential analysis of this fact, see McCloskey and Hale (1983).

5 We have made some assumptions, since the BST do not cover all cases, but the assumptions appear justified. For instance, the examples in the BST do not 
include cases of conjoined plural subjects, but the assumption is that the verb would always be plural if both the conjoined subjects are.

6 There are three examples that deviate from this pattern. The case of the NPs in two such examples, AMC s. 418 and MT s. 5, is unclear. In AMC s. 418 (rell dermáir , nertlia míled 'a huge block and a warrior's stone'), the adjective dermáir can be interpreted as accusative ( $a$-stem) or nominative ( $i$-stem). In MT s. 5 (molad Dé, nemèli fris 'praise of God and lamentation for him'), the final vowel of neméli marks it as ostensibly accusative, although the spelling of final vowels in later manuscripts is a notoriously unreliable guide to actual pronunciation. For our purposes, we count these as nominatives. The third case, MT s. 263, will be dealt with below.

7 See also Hofman (1996: 52), who does not make a choice between the two options. It seems more probable that Lambert is correct, but the form is nonetheless ambiguous and thus excluded here.

8 Following $l$, the singular would have been pronounced $/ \mathrm{t}^{\mathrm{j} e r} /$ and the plural /djer/, but the spelling -lter could represent either pronunciation.

9 One further example would also fit here, but it is unclear how to analyze the verb:

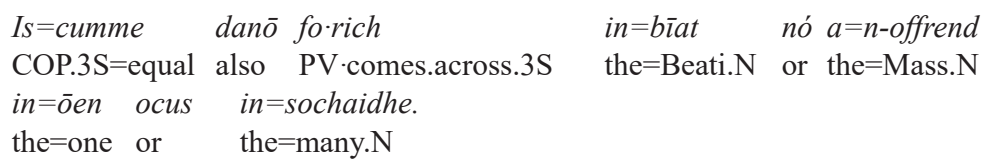
'Also, it is no matter whether the Beati of the Mass reach (?) one person or many.' (POMIC, MT s. 493)

The verb fo rich appears to be a singular, but the form does not appear to belong to any known verb. It is mentioned here because the construction appears to be the same as that in (8a) and (8b) (though with cummae 'equal' for inunn 'same'), but in the end, we cannot be sure. As a result, the example is excluded.

10 Example (9b), like (11c) below, does not form part of the corpus in Table I, since it has a non-conjoined subject. Its relevance is that it allows us to exclude (9a), as well as (11a-b).

11 Examples containing such verbs are only excluded when they may be construed as auxiliaries. The auxiliary usage consists of the possible auxiliary verb followed by a verbal noun or verbal-noun phrase with an optional prepositional phrase that marks the logical subject. When not used as auxiliaries, examples containing these verbs are included for consideration (FB 1. 474, FB 1. 1505). 
12 Ködderitzsch (1997) discusses similar examples in other older Indo-European languages, while Lichtenberk (2000), Schwartz (1988), Aissen (1989) and McNally (1993), among others, discuss the phenomenon more broadly and in theoretical terms.

13 These tokens may also be excluded on the grounds that the conjoined subject (of which the first is pronominal) is discontinuous, and therefore they may involve ellipsis; see section 3.3.

14 For instance:
Ro·benad
uilidetaid in=étaig
dímm.
PRF-cut.PSS.PST.3S majority.A the=clothes.G from.1S
'The whole of my clothing was stripped off me.' (lit. 'One stripped off
the majority of clothes from me.') (POMIC, AMC s. 215)

15 Some accusative 'objects' are not themes and are thus not indicative of a transitive verb. Two classes of such non-thematic accusatives are the somewhat rare use of infixed object pronouns as 'datives' (Thurneysen 1946: 255, §409b) and the somewhat more common use of infixed pronouns with verbs of motion to indicate goal (see (21e)). Note that in both cases, the infixed pronoun alternates with a prepositional phrase, which would suggest that the infixed object is not a theme.

16 Despite the infixed pronoun in this example (i.e. $d o n<d\rangle \cdot t i c$, for earlier Old Irish $d o n d \cdot i c c$ ), we have analyzed this as an intransitive verb, as per our definition above. See also footnote 15.

17 There are no other cases of coordinated subjects in this text, so it is unfortunately impossible to test this contention further.

18 Gwynn and Purton (1911-12: 143, fn.1) suggest reading the subject as ind=gilde nó ind =ben, with two nominatives. Indeed, the reason why the second conjunct would be in the accusative is unclear, but as it stands in the manuscript, the fact remains that this example is simply not a good counter-example to the claims being put forward here.

19 According to the definition of c-command adopted by van Koppen (2007: 126-7), the whole coordinate phrase and the first conjunct are both equally distant and visible from the probe, here the complementizer. Agreement on the probe can therefore only be resolved post-syntactically by the morphological component using the Subset Principle: the probe with the greatest number of agreement features with its goal is selected. 
20 For the possibility of first conjunct agreement in this case, as indicated in (25a), see the discussion in van Koppen (2007: 135-47).

21 For instance, Sheehan (2006: 241-3) uses the behavior of meteorological verbs in Romance languages as crucial evidence for her proposal. In Early Irish, however, meteorological verbs behave quite differently. Essentially, there is one verb feraid 'pour, give forth, shed', whose subject can be any number of nouns referring to meteorological phenomena, such as snechtae 'snow', or flechud/fliuchud 'rain'. Thus they appear to only have referential subjects and not expletive subjects.

22 If 'NP-promotion' passives could have an expletive in SpecTP as argued in the text, this would mean that the 'promotion' does not correspond to movement but chain-formation. This proposal also provides a possible origin for the later spread of the arbitrary-subject passive, which could be analysed as the reanalysis of the NP-promotion passive+expletive pattern. The reanalysis would have occurred while the case system was breaking down such that the NPs could be analysed as either nominative or accusative.

23 Levin and Rappaport Hovav (1995) have challenged the link between unaccusativity and LI, and have engendered a rich debate on the properties of LI. There is no room here to delve into this debate and the implications for our analysis of Old Irish. We therefore leave this for future research. Lash (2015), an unpublished conference paper, goes part of the way towards filling this goal. This paper reported the results of a corpus study of simple (i.e. non-conjoined) subjects found in non-VSO word order in the first recension of the Táin Bó Cúailnge (TBC) (O’Rahilly 1976). For the purposes of the corpus study, non-VSO word order consisted of all situations in which the subject was separated from the verb. This can be represented by the formula: VXS(Y), where $\mathrm{X}$ is a PP or temporal/aspectual adverbial. Modal particles and NP objects were discounted: modal particles because they only distinguish between 'Subject-1' and 'Subject-2', not the internal argument position, and NP objects because it is very likely they are topics in Subject-1 when they are before the subject. Y is an optional fourth phrasal element such as an extra PP or adverb that was included to distinguish between absolute final subjects, which may have other explanations (see (46) in the main text), and clause-medial subjects, such as 'Subject-1', 'Subject-2', or the VP-internal argument position. Out of 1441 sentences surveyed, a roughly equal number of transitive and nontransitive sentences was found: 718 transitive and 723 non-transitive (passive 
and intransitive). Of the transitive sentences surveyed, only two had VXS(Y) order (atotágathar, 1. 235 and conid ro lá, 1. 288), both of which were from poetry, where special conditions apply (such as meter, rhyme, etc.). In contrast, 14 of the non-transitive sentences had VXS(Y). These numbers are given in the table below.

\begin{tabular}{|l|c|c|c|}
\hline $\begin{array}{c}\text { VSX/VXS } \\
\text { in TBC }\end{array}$ & $\begin{array}{c}\text { Non- } \\
\text { Transitive }\end{array}$ & Transitive & $\begin{array}{c}\text { Row } \\
\text { Totals }\end{array}$ \\
\hline VSX & 709 & 716 & 1425 \\
\hline VXS(Y) & 14 & 2 & 16 \\
\hline $\begin{array}{l}\text { Column } \\
\text { Totals }\end{array}$ & 723 & 718 & 1441 \\
\hline
\end{tabular}

Running a Fisher's Exact test on these numbers shows that the distribution is significant: $\mathrm{P}=0.0003991$. This suggests that $\mathrm{VXS}(\mathrm{Y})$, where $\mathrm{X}$ is a $\mathrm{PP}$ or temporal/aspectual adverbial is significantly associated with non-transitive verbs. The study did not distinguish between unaccusative and unergative verbs, but it at least shows that transitive verbs are unlikely. Of course, it is not certain that the Early Irish corpus as a whole would show the same significant distribution, but it is a valid hypothesis to suppose one would find a similar pattern.

25 Default agreement with there-type expletives is also found in some varieties of non-standard English (see Rupp 2005, and references cited therein).

In structures like that of (46), we predict that the plural nota augens (i.e. 3P som) may be attached to the verb in place of pro, in switch-topic contexts for instance.

27 Reference and dates for the salient-unaccusative constructions represented by the verbs in (54) are given here for those examples from before approximately 1500 (the time of the BST): (a) no old examples; (b) no old examples; (c) Táin Bó Cúailnge, Rec.2 (12 ${ }^{\text {th }}$ c., O'Rahilly 1967: 133, 2x); (d) no old examples; (e) no old examples; (f) Táin Bó Cúailnge, Rec.1 (8 ${ }^{\text {th }}$ c. [?], O'Rahilly 1976: 50-1, 11. 1679-80; O’Rahilly 1976: 51-2.1680-81), Táin Bó Cúailnge, Rec.2 (12 ${ }^{\text {th }} \mathrm{c}$., O'Rahilly 1967: 92.3334-5; O'Rahilly 1967: 92.3335); Homily XXXIII in the Leabhar Breac (15 ${ }^{\text {th }}$ c. or earlier, Atkinson 1887: 244.7266); Leabhar Oiris $\left(11^{\text {th }}\right.$ c., Best 1904: 87.11); (g) For examples with methaid see (57) and footnote 30; 
(h) The Battle of Airtech (Middle Irish, Best 1916: 172.9); (i) no old examples; (j) no old examples; (k) Dindsenchas of Mag Tibra (at least 11th c., Gwynn 1913: 434/436: 29-30).

28 See also Táin Bó Cúailnge (Rec.2; O'Rahilly 1967: 133) for a comparable instance of the verb do maid with an infixed pronoun.

29 Reference and dates for the relevant examples are given here following the same guidelines as in footnote 27: (a) Togail na Tebe (12 ${ }^{\text {th }}$ c., Calder 1922: 200.31123), Ferchuitred Medba (Late Middle Irish, Meyer 1913: 21.21), Cath Boinde (late Middle Irish, Ó'Neill 1905: 182.22), Annals of Tigernach (a mid-12th c. entry, Stokes 1897: 55.6), Aided Guill meic Carbada , Aided Gairb Glinne Rigi (Late Middle Irish, Stokes 1893: 428 §50 [LL 112978]); (b) Táin Bo Cúailnge, Rec.1 ( $8^{\text {th }}$ c., 1. TBC, Rec. 1, O'Rahilly 1976 [2006]: 29.939-40, 2. O'Rahilly 1976 [2006]: 124.4142); (c) no old examples; (d) Dindsenchas of Ath Lúain (at least 12 $2^{\text {th }}$ c., Stokes 1894: 465); (e) no old examples; (f) Annals of Ulster, A.D. 1312/1315.3 (14 $4^{\text {th }}$ c., or later; MacCarthy 1893: 424.10); (g) Cáin Aicillne (Old Irish, CIH 486.10, Thurneysen 1925: 363, §23) Cethairsilicht Athgabálae (Old Irish, CIH 402.32); (h) Táin Bó Cúailnge, Rec.2 (12 ${ }^{\text {th }}$ c., O'Rahilly 1967: 50.1854); (i) Togail na Tebe (12 ${ }^{\text {th }}$ c., Calder 1922: 216.3364, 296.4594), Cath Catharda (12 ${ }^{\text {th }}$ c., Stokes 1909: 408.5561).

30 See also Cethairsilicht Athgabálae (CIH 402.32), where the sentence is difficult to interpret, but the verb may have a referential null subject.

31 Where a sentence contains two clauses, each with a relevant conjoined phrase, we provide the conjoined phrase after the citation.

32 It could be argued that this example is simply a list:

Bi $[i] t$ di bai .x. leis, leth n-arathair, capal fognama, be.3P 2 cows.N 10 with.3SM half.N plough.G horse.N work.G and ech immrimme. horse. $\mathrm{N}$ riding. $\mathrm{G}$

'He has 12 cows, half a plough, a work horse and a riding horse.' $(C G \S 13)$

The elements are connected in part asyndetically, rather than the more usual case of having, / ocus 'and' between each element. Since the example is excluded as having a discontinuous subject, the list-like nature makes no real difference. 


\section{References}

Aissen, J. (1989). Agreement Controllers and Tzotzil Comitatives, Language 65, $518-36$.

Alexiadou, A. and E. Anagnostopoulou (1998). Parametrizing AGR: Word Order, V-Movement and EPP-Checking, Natural Language \& Linguistic Theory 16.3, 491-539.

Atkinson, R. (ed.) (1887). Passions and Homilies from Leabhar Breac. Dublin: Royal Irish Academy.

Bauer, B. (ed.) (2015). The online database of the Old Irish Priscian Glosses. http:// www.univie.ac.at/indogermanistik/priscian/

Best, R. (ed.) (1904). The Leabhar Oiris, Ériu 1, 74-112.

Best, R. (ed.) (1916). The Battle of Airtech, Ériu 8, 170-90.

Biberauer, T. and J. van der Wal (2012). Why Languages Don't Like Expletives, handout for Syntax of the World's Languages V, Dubrovnik, October 2012.

Binchy, D. (ed.) (1941). Crith Gablach, Mediaeval and Modern Irish Series 11. Dublin: Dublin Institute for Advanced Studies.

Binchy, D. (ed.) (1978). Corpus Iuris Hibernici: ad fidem codicum manuscriptorum. Dublin: Dublin Institute for Advanced Studies.

Breatnach, L. (1994). An Mheán-Ghaelige. In L. Breatnach, K. McCone, D. McManus, N. Williams and C. Ó hÁinle (eds), Stair na Gaelge in ómós do: Pádraig Ó Fiannachta. Maigh Nuad: Roinn na Sean-Ghaelige, Coláiste Phádraig, Maigh Nuad, pp. 221-333.

Burzio, L. (1981). Intransitive Verbs and Italian Auxiliaries. PhD thesis (MIT).

Burzio, L. (1986). Italian Syntax: A Government-Binding Approach. Dordrecht: Reidel.

Calder, G. (ed.) (1922). Togail na Tebe: The Thebaid of Statius. Cambridge: Cambridge University Press.

Cardinaletti, A. (1997). Subjects and Clause Structure. In L. Haegeman (ed.), The New Comparative Syntax. London: Longman, pp. 33-63.

Carey, J. (ed.) (1994). An Edition of the Pseudo-Historical Prologue to the Senchas Már, Ériu 45, 1-32.

Carnie, A. (1995). Head Movement and Non-Verbal Predication. PhD thesis (MIT). Carnie, A., H. Harley and E. Pyatt (1994). The Resurrection: Raising to Comp? Some Evidence from Old Irish, Studies in the Linguistic Sciences 24, 85100 . 
Charles-Edwards, T. and F. Kelly (ed.) (1983). Bechbretha: An Old Irish Law-Tract on Bee-keeping, Early Irish Law Series 1. Dublin: Dublin Institute for Advanced Studies.

Chung, S. and J. McCloskey (1987). Government, Barriers, and Small Clauses in Modern Irish, Linguistic Inquiry 18.2, 173-237.

Cinque, G. (1999). Adverbs and Functional Heads: A Cross-Linguistic Perspective. Oxford: Oxford University Press.

Citko, B. (2003). Agreement Asymmetries in Coordinate Structures. In O. Arnaudova, W. Browne, M. L. Rivera and D. Stojanovic (eds), Formal Approaches to Slavic Linguistics 12: The Ottawa Meeting. Ann Arbor, MI: Michigan Slavic Publications, pp. 91-107.

Dottin, G. (1913). Manuel d'irlandais moyen. Vol. 1: Grammaire. Paris: Champion.

Graver, J. (2011). The Syntax and Development of the Old Irish Autonomous Verb. In: A. Carnie (ed.), Formal Approaches to Celtic Linguistics. Newcastle-uponTyne: Cambridge Scholars Publishing, pp. 41-63.

Griffith, A. (2009a). A Note on Pronominal Coordination in Old Irish, Die Sprache 48, 66-70.

Griffith, A. (2009b). The Etymology of OIr. ocus 'and'. Handout for Tionól, Dublin Institute for Advanced Studies, 2009. http://www.univie.ac.at/indogermanistik/ griffith_papers.htm (viewed: 1 January 2010).

Griffith, A. (2012). Small Clauses and Coordination in Old Irish. Handout for talk at New Perspectives in Celtic Syntax workshop, University of California, Berkeley, 7-8 September, 2012.

Griffith, A. (ed.) (2013). Milan Glosses Database http://www.univie.ac.at/ indogermanistik/milan_glosses.htm

Gwynn, E. (ed.) (1903-35 [1991]). The Metrical Dindshenchas. 5 vols., vol. 3 (1913). Dublin: Dublin Institute for Advanced Studies.

Gwynn, E. and W. Purton (ed.) (1911-12). Monastery of Tallaght, Proceedings of the Royal Irish Academy, Section C: Archaeology, Celtic Studies, History, Linguistics, Literature 29, 115-79.

Hankamer, J. and I. Sag (1976). Deep and Surface Anaphora. Linguistic Inquiry 7, 391-426.

Herbert, M. (2009). Medieval Collections of Ecclesiastical and Devotional Materials: Leabhar Breac, Liber Flavus Fergusiorum and The Book of Fenagh. In B. Cunningham, S. FitzPatrick and P. Schnabel (eds), Treasures of the Royal Irish Academy Library. Dublin: Royal Irish Academy, pp. 33-43. 
Hofman, R. (1996). The Sankt Gall Priscian Commentary. Part 1. Volume 2: Translation and Commentary; Indices. Münster: Nodus Publikationen.

Hollo, K. (ed.) (2005). Fled Bricrenn ocus Loinges Mac nDuil Dermait and its Place in the Irish Literary and Oral Narrative Traditions, Maynooth Medieval Irish Texts 2. Maynooth: Department of Old Irish, National University of Ireland Maynooth.

Hull, V. (ed.) (1928). The Middle Irish Version of Bede's De locis sanctis, Zeitschrift für celtische Philologie 17, 225-40.

Isaac, G. (2003). Prospects in Old Irish Syntax, Zeitschrift für celtische Philologie 53, 181-97.

Johannessen, J. (1998). Coordination. New York and Oxford: Oxford University Press.

Johnson, K. (2009). Gapping is not (VP-) Ellipsis, Linguistic Inquiry 40, 289-328. Kimpton, B. (ed.) (2009). The Death of Cú Chulainn: A Critical Edition of the Earliest Version of Brislech Mór Maige Muirthemni with Introduction, Translation, Notes, Bibliography and Vocabulary, Maynooth Medieval Irish Texts 6. Maynooth: Department of Old Irish, National University of Ireland Maynooth.

Ködderitzsch, R. (1997). Indoiranisch-Keltisches, Zeitschrift für celtische Philologie 49-50, 382-95.

Lambert, P.-Y. (1996). Les différents strates de gloses dans le ms. de Saint-Gall no 904 (Priscien). In M. Richter and P. Ní Chatháin (eds), Ireland and Europe in the Early Middle Ages: Learning and Literature. Stuttgart: Klett-Cotta, pp. 187-94.

Lash, E. (ed.) 2014a. The Parsed Old and Middle Irish Corpus (POMIC). https:// www.dias.ie/celt/celt-publications-2/celt-the-parsed-old-and-middle-irishcorpus-pomic/

Lash, E. (2014b). Subject Positions in Old and Middle Irish, Lingua 148, 278-308.

Lash, E. (2015). 'Non-Canonical' Subject Positions in Passive and Intransitive Sentences. Handout for Tionól, Dublin Institute for Advanced Studies, 19-21 November 2015.

Lash, E. (2016). The Morphosyntax of Subject-Verb Agreement in Early Irish. Presentation for Workshop on Verbs, hosted by Research Network: Morphosyntactic Change through Corpora in German and Beyond, University of Cambridge 15-16 September 2016.

Le Mair, E. (2015). Non-Canonical Subject Marking in Old Irish. XV International Congress of Celtic Studies, Glasgow, 13-17 July 2015. 
Ledgeway, A. (2013). Testing Linguistic Theory and Variation to their Limits: The Case of Romance, Corpus 12, 271-327.

Levin, B. and M. Rappaport Hovav (1995). Unaccusativity. Cambridge MA: MIT Press.

Lichtenberk, F. (2000). Inclusory Pronominals, Oceanic Linguistics 39.1, 1-32.

MacCarthy, B. (ed.) (1893). Annala Uladh: Annals of Ulster otherwise Annala Senait, Annals of Senat. vol. ii. Dublin: Royal Irish Academy.

Mac Cana, P. and E. Slotkin (ed.) (2014). Fled Bricrenn. http://irishtextssociety.org/ texts/fledbricrenn.html.

Mac Donncha, F. (1976). Medieval Irish Homilies. In M. McNamara (ed.), Biblical Studies: The Medieval Irish Contribution. Dublin: Dominican Publications, pp. 59-71.

Mac Giolla Easpaig, D. (1980). Aspects of Variant Word Order in Early Irish, Ériu 31, 28-38.

Manzini, M. R. and L. M. Savoia (2002). Parameters of Subject Inflection in Italian Dialects. In P. Svenonius (ed.), Subjects, Expletives, and the EPP. Oxford: Oxford University Press, pp. 157-99.

McCloskey, J. (1986). Inflection and Conjunction in Modern Irish, Natural Language and Linguistic Theory 4.2, 245-81.

McCloskey, J. (1991). A Note on Agreement and Coordination in Old Irish. In S. Chung and J. Hankamer (eds), A Festschrift for William Shipley. Santa Cruz, CA: Syntax Research Center, pp. 105-14.

McCloskey, J. (1996). Subjects and Subject Position in Irish. In R. Borsley and I. Roberts (eds), Syntax of the Celtic Languages: A Comparative Perspective. Cambridge: Cambridge University Press, pp. 241-83.

McCloskey, J. (1997). Subjecthood and Subject Positions. In L. Haegeman (ed.), Elements of Grammar: Handbook of Generative Syntax. Dordrecht: Kluwer Academic Publishers, pp. 197-235.

McCloskey, J. (2001). The Distribution of Subject Properties in Irish. In W. Davies and S. Dubinsky (eds), Objects and Other Subjects: Grammatical Functions, Functional Categories and Configurationality. Studies in Natural Language and Linguistic Theory, vol. 52. Dordrecht, Boston, MS and London: Kluwer Academic Publishers, pp. 157-92.

McCloskey, J. (2014). Irish Existentials in Context, Syntax 17.4, 343-84.

McCloskey, J. and K. Hale (1984). On the Syntax of Person-Number Inflection in Modern Irish, Natural Language and Linguistic Theory 1, 487-533. 
McKenna, L. (ed.) (1944 [1979]). Bardic Syntactical Tracts. Dublin: Dublin Institute for Advanced Studies.

McNally, L. (1993). Comitative Coordination: A Case Study in Group Formation, Natural Language and Linguistic Theory 11.3, 347-79.

Meid, W. (1968). Indo-European and Celtic, Scottish Studies 12: 45-56.

Meid, W. (ed.) (2015). The Romance of Froech and Findabair, or, the Driving of Froech's Cattle. Innsbruck: Innsbrucker Beiträge zur Kulturwissenschaft.

Mendikoetxea, A. (2006). Unergatives that 'Become' Unaccusatives in English Locative Inversion: A Lexical-Syntactic Approach. In C. Copy and L. Gournay (eds), Points de Vue sur l'Inversion. (Cahiers de Recherche en Grammaire Anglaise de l'Énonciation. Tome 9). Paris: Editions Orphys, pp. 133-55.

Meyer, K. (ed.) (1913). Ferchuitred Medba. In O. J. Bergin, R. I. Best, K. Meyer, and J. G. O'Keeffe (eds) Anecdota from Irish Manuscripts, volume 5. Halle: Max Niemeyer, pp. 17-21.

Newton, G. (2006). The Development and Loss of the Old Irish Double System of Verbal Inflection. $\mathrm{PhD}$ thesis (University of Cambridge).

Ó Cathasaigh, T. (1990). On the Early-Irish Prepositional Relative Without Antecedent, Celtica 21, 418-26.

Ó Cuív, B. (1994). The Concepts of 'Correct' and 'Faulty' in Medieval Irish Bardic Tradition. In R. Bielmeier, R. Stempel and R. Lanszweert (eds), Indogermanica et Caucasica: Festschrift für Karl Horst Schmidt zum 65. Geburtstag. Berlin: De Gruyter, pp. 395-406.

Ó Máille, T. (1912). Contributions to the History of the Verbs of Existence in Irish, Е́riu 6, 1-102.

Ó Domhnaill, C. (ed.) (2005). Talland Étair: A Critical Edition with Introduction, Translation, Notes, Bibliography and Vocabulary, Maynooth Medieval Irish Texts 4. Maynooth: Department of Old Irish, National University of Ireland Maynooth. O’Brien, M. A. (1938). Varia. II, Ériu 12, 236-44.

O’Neill, J. (ed.) (1905). Cath Boinde, Ériu 2, 173-85.

O’Rahilly, C. (ed.) (1967). Táin Bó Cúalnge from the Book of Leinster. Dublin: Dublin Institute for Advanced Studies.

O’Rahilly, C. (ed.) (1976). Táin Bó Cúailnge: Recension I. Dublin: Dublin Institute for Advanced Studies.

Perlmutter, D. M. (1978). Impersonal Passives and the Unaccusative Hypothesis. In J. J. Jaeger et al. (eds), Proceedings of the 4th Annual Meeting of the Berkeley Linguistics Society. Berkeley, CA: Berkeley Linguistic Society, pp. 157-89. 
Rupp, L. (2005). Constraints on Nonstandard -s in Expletive There Sentences: A Generative-Variationist Perspective, English Language and Linguistics 9.2, 255-88.

Russell, P., S. Arbuthnot and P. Morán (eds) (2010). Early Irish Glossaries Database (EIGD). http://www.asnc.cam.ac.uk/irishglossaries/.

Safir, K. (1982). Syntactic Chains and the Definiteness Effect. PhD thesis (MIT).

Schumacher, S. (2004). Die keltischen Primärverben: ein vergleichendes etymologisches und morphologisches Lexikon. Innsbruck: Institut für Sprachen und Literaturen der Universität Innsbruck.

Schwartz, L. (1988). Asymmetric Feature Distribution in Pronominal 'Coordination'. In M. Barlow and C. A. Ferguson (eds), Agreement in Natural Language. Palo Alto, CA: Center for the Study of Language and Information, pp. 237-49.

Sheehan, M. (2006). The EPP and Null Subjects in Romance. PhD thesis (Newcastle University).

Sheehan, M. (2016). Subjects, Null Subjects and Expletives in Romance. In S. Fischer and S. Gabriel (eds), Manuals of Romance Linguistics (MRL): Grammatical Interfaces. Berlin: Mouton de Gruyter, pp. 329-62.

Stassen, L. (2000). AND-Languages and WITH-Languages, Linguistic Typology 4, $1-54$.

Stokes, Wh. (ed.) (1877). Three Middle Irish Homilies on the Lives of Saints Patrick, Brigit, and Columba. Calcutta: privately printed.

Stokes, Wh. (ed.) (1893). The Violent Deaths of Goll and Garb, Revue Celtique 14, 396-449.

Stokes, Wh. (ed.) (1894). The Prose Tales in the Rennes Dindsenchas, Revue Celtique 15, 272-336, 418-84.

Stokes, Wh. (ed.) (1897). The Annals of Tigernach, Revue Celtique 18, 9-59, 150303, 374-91.

Stokes, Wh. (ed.) (1909). In Cath Catharda: The Civil War of the Romans. An Irish Version of Lucan's Pharsalia. In E. Windisch and Wh. Stokes (eds), Irische Texte mit Übersetzungen mit Wörterbuch, vol. 4. S. Leipzig: Hirzel, pp. 1-581.

Stokes, Wh. and J. Strachan (ed.) (1901). Thesaurus Palaeohibernicus. Vol. 1. Cambridge: Cambridge University Press.

Thurneysen, R. (1925). Zum syntaktischen Gebrauch des Nominativs im Irischen, Kuhn's Zeitschrift 53, 82-6.

Thurneysen, R. (1946). Grammar of Old Irish. Dublin: Dublin Institute for Advanced Studies. 
Van Koppen, M. (2007). Agreement with Coordinated Subjects: A Comparative Perspective, Linguistic Variation Yearbook 7, 121-61.

Van Valin, R. D. Jr. (1990). Semantic Parameters of Split Intransitivity, Language 66, 221-60.

Vikner, S. (1995). Verb Movement and Expletive Subjects in the Germanic Languages. Oxford: Oxford University Press.

White, N. (ed.) (2006). Compert Mongáin and Three Other Early Mongán Tales: A Critical Edition with Introduction, Translation, Textual Notes, Bibliography and Vocabulary, Maynooth Medieval Irish Texts 5. Maynooth: Department of Old Irish, National University of Ireland Maynooth.

Windisch, E. (ed.) (1892). De Chophur in Da Muccida. In E. Windisch and Wh. Stokes (eds), Irische Texte mit Übersetzungen und Wörterbuch, vol. 3.1. Leipzig: S. Hirzel Verlag, pp. 230-78. 